\title{
Saline lakes as barriers against pollution: a multidisciplinary overview
}

\author{
Nicolás Valiente ${ }^{1,2, *}$ (D), Franz Jirsa ${ }^{3,4}$ (iD and Juan José Gómez-Alday² ${ }^{\text {ID }}$
}

${ }^{1}$ Centre for Biogeochemistry in the Anthropocene, Department of Biosciences, Section for Aquatic Biology and Toxicology, University of Oslo, PO Box 1066 Blindern, 0316 Oslo, Norway.

2 Biotechnology and Natural Resources Section, Institute for Regional Development (IDR), University of CastillaLa Mancha (UCLM), Campus Universitario s/n, 02071 Albacete, Spain.

3 Institute of Inorganic Chemistry, Faculty of Chemistry, University of Vienna, Waehringer Strasse 42, 1090 Vienna, Austria.

4 Department of Zoology, University of Johannesburg, PO Box 524, Auckland Park, 2006 Johannesburg, South Africa.

* Corresponding author: n.v.parra@ibv.uio.no

Received: $01 / 02 / 21 \quad$ Accepted: $15 / 06 / 21$

\begin{abstract}
Saline lakes as barriers against pollution: a multidisciplinary overview

Saline lakes are subject to numerous environmental impacts closely related to human activities, including mining, desiccation and pollution. These lakes are mostly located in arid and semi-arid regions located in endorheic basins, which combined with the low precipitation and high evaporation rates typical for these regions, may lead to the accumulation of pollutants. Saline lakes are polluted mainly through inputs of agricultural wastewater along with organic and inorganic wastes from domestic and industrial sources. The excessive anthropogenic loading of nutrients, especially nitrogen $(\mathrm{N})$, can result in eutrophication of these ecosystems. Here, the importance of pollution in saline lakes was assessed, placing special emphasis on $\mathrm{N}$ pollution and its attenuation in aquatic interfaces. Two main interfaces are present in saline lakes: (1) the sediment-water interface; (2) the freshwater-saltwater interface. While the former is the most important one for microbial turnover, the latter plays also a key role in pollution attenuation based on solute transport by density-driven flows. The study of how saline lakes can attenuate $\mathrm{N}$ pollutants (e.g. nitrate) is a step forward in preserving the good ecological status of these ecosystems. This work highlights the need of integrating a wide range of techniques from different disciplines such as limnology, hydrogeology, geochemistry or microbial ecology for such studies. The effective application of conservation policies by managers will depend on the degree of knowledge of these systems.
\end{abstract}

Key words: saline lakes, nitrogen cycle, attenuation of pollutants, groundwater, microbial ecology, aquatic interfaces

\section{RESUMEN}

\section{Los lagos salados como barreras contra la contaminación: una visión multidisciplinar}

Los lagos salados están sujetos a numerosos impactos ambientales estrechamente relacionados con las actividades humanas, como la minería, la desecación de éstos y la contaminación. Estos lagos se localizan principalmente en regiones áridas y semiáridas asociadas a cuencas endorreicas, lo que unido a las bajas precipitaciones y las altas tasas de evaporación típicas de estas regiones, favorecen la acumulación de contaminantes. La contaminación de los lagos salados proviene principalmente de los aportes de aguas residuales agrícolas, así como de desechos orgánicos e inorgánicos de fuentes domésticas e industriales. La excesiva carga antropogénica de nutrientes, especialmente de nitrógeno ( $N$ ), provoca la eutrofización de estos ecosistemas. En este trabajo se aborda la importancia de la contaminación en los lagos salados, con especial énfasis en la contaminación por nitrógeno y su atenuación en las interfases acuáticas. Las dos principales interfases en los lagos salados son: 1) la interfase sedimentos-agua; 2) la interfase agua dulce-agua salada. Mientras que la primera es la más activa desde el punto de vista microbiano, la segunda desempeña un papel fundamental en la atenuación de la contaminación basada en el transporte de solutos por los fujos variables de la densidad. El estudio de cómo los lagos salados pueden atenuar compuestos nitrogenados 
(p. ej. nitrato) es un paso importante en la conservación del buen estado ecológico de esos ecosistemas. Este estudio resalta la importancia de integrar una amplia gama de técnicas de diferentes disciplinas como la limnología, la hidrogeología, la geoquímica o la ecología microbiana para este tipo de estudios. Del grado de conocimiento de estos sistemas dependerá la aplicación efectiva de políticas de conservación por parte de los gestores.

Palabras clave: lagos salados, ciclo del nitrógeno, atenuación de contaminantes, aguas subterráneas, ecología microbiana, interfases acuáticas

This is an open-access article distributed under the terms of the Creative Commons Attribution-NonCommercial 4.0 International (CC BY-NC 4.0) License.

\section{INTRODUCTION}

Lakes are complex ecosystems formed by different habitats coupled by biological, physical and chemical processes (Schindler \& Scheuerell, 2002). They act as integrators of their surroundings by reflecting the combined effects of the catchment, vegetation, geology and human history (Vincent, 2018), and provide important ecosystem services such as water regulation and habitat provision for biodiversity (Wurtsbaugh et al., 2017). The scientific, ecological, sociological, recreational, and economic benefits of saline lakes are diverse yet not easily monetized. In chemical terms, lakes are bioreactors that collect and process washed in materials from the catchment, always governed by the biodiversity inhabiting them. Their water chemistry not only determines aspects such as which organisms are able to inhabit them, but also how they are connected with the rest of the landscape. Depending on their concentration of dissolved salts (i.e. salinity), lakes can be divided into freshwater and saline lakes. Hammer (1986) classified lake waters as follows: fresh lake waters with salinities up to $0.5 \%$, subsaline waters between 1 and $3 \%$, and saline waters those with salinities over $3 \%$. As a reference, average seawater has a salt content of $35.5 \%$ (Schagerl, 2016).

Globally, saline lakes are common but not homogeneously distributed. Some factors make it difficult to estimate the number of saline lakes around the world. These factors are, among others, their ephemeral character, strong seasonal fluctuations due to their shallowness or the complex hydrodynamics in endorheic basins. Messager et al. (2016) estimated approximately 1421000 lakes with a surface area of at least
$0.01 \mathrm{~km}^{2}$. These estimations showed that freshwater and saline lakes together cover $1.8 \%$ of the global land area, holding only about $0.015 \%$ of the total water on Earth (Sladen, 2012). According to the most recent estimations (Babkin, 2003), the volume of freshwater lakes globally is about $91000 \mathrm{~km}^{3}$, whereas saline lakes account for $85400 \mathrm{~km}^{3}$. However, the highest abundance of lakes is found at boreal and Arctic regions $\left(45^{\circ} \mathrm{N}\right.$ to $\left.75^{\circ} \mathrm{N}\right)$ (Verpoorter et al., 2014), which may suggest that freshwater lakes are in greater abundance. The main characteristics of some representative saline lakes around the world are shown in Table 1. The largest saline waterbody is contained in the Caspian Sea, with $91 \%$ of the total volume. However, special mention must be made to insufficiently studied regions such as Victoria Land (Antarctica; Porcino et al., 2020), the East African Rift System with some of the most representative soda lakes in the world (Jirsa et al., 2013; Schagerl, 2016), or the large lakes $\left(>100 \mathrm{~km}^{2}\right)$ occupying paleodrainage areas of Australia (De Deckker, 1983).

Freshwater lakes in temperate regions often undergo seasonal thermal stratification when large density differences occur between the warm water at the surface (epilimnion) and the cold water at the bottom (hypolimnion), both separated by the thermocline. However, many saline lakes are meromictic, meaning that their water layers do not intermix (Valero-Garcés \& Kelts, 1995; Degermendzhy et al., 2010). In saline lakes, such mixing does not take place because of the strong density difference caused by salinity gradient at the boundary (halocline) of the surface mixed layer (mixolinion) and the often-anoxic bottom layer (monimolimnion). Depending on their connections to groundwater bodies, saline lakes can 
be classified as terminal discharge lakes, recharge lakes, and through-flow lakes (Cartwright et al., 2009). Saline lakes are mostly located in endorheic basins from arid and semi-arid regions. Most saline lake basins have been formed by three main actions: tectonic movements, volcanism, and glacial action (Hammer, 1986). These basins are often closed drainage areas with no outlet other than evaporation. Annual water loss by evaporation generally exceeds annual inflow by precipitation, surface watercourses (e.g. rivers, streams), and groundwater discharge. As a result, prolonged intervals with a negative hydrological balance yield saline lakes (Schagerl, 2016). Three climatic factors determine the natural development of saline lakes: temperature, net evaporation, and precipitation (Williams, 2002). These lakes respond to climate changes by varying water level, salinity, and hydrogeochemistry (Eugster \& Hardie, 1978; Yechieli \& Wood, 2002).

From an ecological perspective, saline lakes are characterized by high primary productivity (Hammer, 1981) due to their capacity to recycle nutrients more efficiently than freshwater systems (Wurtsbaugh et al., 2017). In that sense, some authors have emphasized the role of saline lakes in the global carbon $(\mathrm{C})$, nitrogen $(\mathrm{N})$ and sulfur $(\mathrm{S})$ cycles (Horne \& Galat, 1985; Joye et al., 1999; Duarte et al., 2008; Osburn et al., 2011; Sorokin et al., 2011; Sorokin et al., 2014), arguing that greenhouse gas emissions from such lakes during organic matter degradation can be noticeable (Camacho et al., 2017; Barbiero et al., 2018). Primary productivity in such ecosystems is mainly related to halophilic and halotolerant microorganisms (cyanobacteria, phototrophic bacteria, etc.) (Oren, 1994; Jones et al., 1998). These highly active microorganisms are in turn responsible for the degradation of allochthonous dissolved organic matter (DOM), i.e. nutrients, and hence the noteworthy levels of organic compounds frequently present in saline ecosystems (Walker, 1973; Waiser \& Robarts, 2000; Schagerl, 2016). Among these lakes, hypersaline ones are rich in organisms adapted to extreme conditions through diverse evolutionary strategies, providing them with a wide range of unique biogeochemical features (Paul \& Mormile, 2017). Therefore, hypersaline brines also host substantial populations of anaerobic heterotrophs (Grant, 2004). For this reason, hypersaline environments have been studied as potential places for the long-term preservation of life on other planets (Litchfield, 1998; Prieto-Ballesteros et al., 2003).

The goal of this work is to briefly summarize the role of saline lakes in nutrient recycling and natural attenuation of pollutants, with special emphasis on the nitrogen cycle, given its close relationship with eutrophication. In doing so, we hope to encourage interdisciplinary thinking and provide a step forward in preserving the ecological status of such unique ecosystems by influencing decision-making processes. The integration of a wide range of techniques from different disciplines such as limnology, hydrogeology, hydrogeochemistry or microbial ecology in the study of saline lakes is also discussed.

\section{ENVIRONMENTAL IMPACTS: POLLUTION}

Saline lakes are subject to numerous environmental impacts, closely related to human activities (Zadereev et al., 2020). These impacts have adverse, mostly irreversible effects involving important ecological changes. Among these impacts, effects derived from climate change like decreasing precipitation and increasing evaporation in arid regions must be highlighted. Endorheic basins, where saline lakes are usually located, are particularly sensitive to climate change as their water levels are strongly influenced by the delicate balance between precipitation and evaporation (Prange et al., 2020).

In addition, saline lakes are impacted by other human activities in their catchment like mining, surface inflow diversions, groundwater withdrawals, and pollution (Williams, 2002). The diversion of freshwater inflows due to increased water use by humans alters the hydrological budget, which has led to the decrease of saline lakes across the globe (Wurtsbaugh et al., 2017; Hossein Mardi et al., 2018; Hassani et al., 2020). As an example, the lake area of the Aral Sea has been reduced by $74 \%$ and its volume by $90 \%$ due to withdrawals of water for irrigation during the last decades (Micklin, 2007). When saline lakes are connected to the underlying aquifer, groundwater abstractions for urban, industrial and/or agricultural uses 
Table 1. Major characteristics of representative saline lakes around the world. Note that salinity values presented here refer to maximum values listed in the respective studies. Principales características de los lagos salados representativos del mundo. Obsérvese que los valores de salinidad presentados aquí se refieren a los valores máximos indicados en sus respectivos estudios.

\begin{tabular}{|c|c|c|c|c|c|}
\hline Lake & Country & $\begin{array}{l}\text { Area } \\
\left(\mathrm{km}^{2}\right)\end{array}$ & $\begin{array}{l}\text { Maximum } \\
\text { depth (m) }\end{array}$ & $\begin{array}{l}\text { Salinity } \\
(\% 0)\end{array}$ & References \\
\hline Caspian Sea & $\begin{array}{l}\text { Azerbaijan, Iran, } \\
\text { Kazakhstan, Russia, } \\
\text { Turkmenistan }\end{array}$ & 378000 & 1025 & 15 & Babkin (2003), Pervov et al. (2003) \\
\hline Urmia & Iran & 5800 & 16 & 300 & Williams (1996), Babkin (2003) \\
\hline Aral Sea & Kazakhstan, Uzbekistan & 8550 & 28.3 & 100 & Micklin (2007) \\
\hline Dead Sea & Israel, Jordan, Palestine & 940 & 320 & 340 & Williams (1996), Yechieli et al. (1998) \\
\hline Balkhash & China, Kazakhstan & 17000 & 27 & 7 & Williams (1996) \\
\hline Dabuxun & China & 184 & 0.4 & 360 & Yu et al. (2001) \\
\hline Qinghai & China & 4278 & 26.5 & 14 & Lister et al. (1991) \\
\hline Van & Turkey & 3570 & 450 & 22 & Kempe et al. (1991) \\
\hline Great Salt Lake & United States & 4660 & 14 & 250 & Wurtsbaugh \& Berry (1990) \\
\hline Salton Sea & United States & 891 & 12 & 33 & Williams (1996) \\
\hline Mono & United States & 158 & 45.7 & 95 & Williams (1996) \\
\hline Mar Chiquita & Argentina & 5770 & 8.6 & 360 & Reati et al. (1996) \\
\hline Salar de Uyuni & Bolivia & 10500 & - & 271 & Schmidt (2010) \\
\hline Natron & Tanzania & 000 & 0.5 & 12 & Williams (1996), Schagerl (2016) \\
\hline Assal & Djibouti & 54 & 40 & 277 & Schagerl (2016) \\
\hline Nakuru & Kenya & 42 & 4.6 & 62 & Jirsa et al. (2013), Schagerl (2016) \\
\hline Bogoria & Kenya & 33 & 9 & 36 & Jirsa et al. (2013), Schagerl (2016) \\
\hline Eyre & Australia & 8430 & 5.7 & 310 & Jankowski \& Jacobson (1989) \\
\hline Corangamite & Australia & 233 & 4.9 & 50 & Williams (1996) \\
\hline Tyrrell & Australia & 300 & 0.5 & 160 & Heidelberg et al. (2013) \\
\hline Elton & Russia & 155 & 0.6 & 300 & Argaman et al. (2012) \\
\hline Gallocanta & Spain & 5.6 & 0.1 & 37 & Pearson et al. (2008) \\
\hline Chiprana & Spain & 0.3 & 5.6 & 73 & Vila et al. (2002) \\
\hline Fuente de Piedra & Spain & 13.5 & 0.5 & 220 & García \& Niell (1993) \\
\hline Pétrola Lake & Spain & 1.8 & 2 & 50 & Valiente et al. (2018) \\
\hline
\end{tabular}

may alter the hydroperiod of the waterbody by decreasing subsurface and surface runoff inputs. As a result, a disconnection of the lake from the aquifer and progressive desiccation can occur (Hosseini-Moghari et al., 2020).

Desiccation of lakes also causes chemical changes that promote the increase in salinity due to evapoconcentration. Clearance of the natural vegetation and the discharge of saline agricultural wastewater (irrigation return flows) within catchments also contribute to modifying the pristine chemical composition, and ultimately, to salinization. This threat, particularly important in arid regions, produces important effects such as decreases in biodiversity or changes in the natural character of aquatic ecosystems (Williams, 
1999). Due to these human actions leading to salinization, it is arguable when a surface waterbody should be considered saline because of this impact, and how the native biodiversity may respond to salinization (Dugan et al., 2017; He et al. 2017). Finally, mining is the main human activity affecting the beds of dry saline lakes, but also has other impacts on saline lakes, including pollutant spills (Dumont, 1995) and heavy metal leaching (Nriagu et al., 1982; Nagajyoti et al., 2010).

Pollution of saline lakes occurs mainly through inputs of agricultural wastewater and farming, including pesticides and drugs, as well as organic and inorganic wastes from domestic and industrial sources. It is a common misconception that saline lakes will respond to pollution in the same way as freshwater lakes, and usually the same environmental criteria are used by environmental protection agencies for both (Williams, 1981). Saline lakes are located in closed hydrological systems. This, combined with low precipitation and high evaporation rates typical for arid and semi-arid regions, leads to accumulate many pollutants compared to freshwater systems (Williams, 2002).

Salinity also plays an important role in the bioavailability of labile organic matter and thus in the release of nutrients. Humic substances are an important shuttle for transporting allochthonous $\mathrm{N}$, but at certain salinity, salt ions can displace the poorly bound amino groups of the humic structure, releasing them into the environment (Bronk et al., 2010). Lacustrine pollution is often associated with eutrophication, promoted by the excessive anthropogenic loading of limiting nutrients like phosphorus (P) and N. Focusing on the latter, it is an essential component of biomolecules, including amino acids, nucleic acids, and chlorophylls. Thus, its availability controls many aspects of ecosystem productivity. Among $\mathrm{N}$ species, nitrate $\left(\mathrm{NO}_{3}{ }^{-}\right)$is a widespread contaminant responsible for water degradation. The Nitrate Directive (91/676/EEC) is the main European reference for the protection of waterbodies from nitrate contamination. In groundwater, the Groundwater Directive (2006/118/EC) considers $\mathrm{NO}_{3}{ }^{-}$one of the most significant contaminants that could prevent reaching the goals of the Water Framework Directive (2000/60/EC). $\mathrm{NO}_{3}{ }^{-}$contamination affects groundwater due to its poten- tial negative effects on human health (Fraser \& Chilvers, 1981; Gulis et al., 2002). The $\mathrm{NO}_{3}{ }^{-}$concentration threshold established by the European Directive 98/83/CE for drinking water supplies is $50 \mathrm{mg} / \mathrm{L}$. In the environment, $\mathrm{NO}_{3}{ }^{-}$increases primary production in surface waters and, as a consequence, may lead to $\mathrm{O}_{2}$ deficiency and further eutrophication of surface water bodies (Vitousek et al., 1997). Excessive use of fertilizers in agriculture, along with wastewater spill outs from urban industrial sources, are the principal sources of $\mathrm{NO}_{3}-$ in the environment. However, despite the above-mentioned ecological differences between freshwater and saline lakes, there are no specific regulations to protect the latter.

The application of agricultural chemicals provides not only macronutrients (e.g. $\mathrm{N}$ and $\mathrm{P}$ ) and micronutrients (e.g. copper $(\mathrm{Cu})$ and zinc $(\mathrm{Zn})$ ), but also compounds known for their toxic properties like other trace metals (e.g. cadmium (Cd) and lead (Pb); Otero et al., 2005) or even endocrine disrupting chemicals (EDCs) (Menchén et al., 2020). EDCs are exogenous substances that might lead to endocrine disruption in living organisms, thus affecting the ecological status of natural water bodies. Trace metal accumulation, including heavy metals, is also a matter of concern in aquatic ecosystems (Tang et al., 2014). Whereas some of them are essential for living organism when occurring at trace levels, overexposure to heavy metals has negative effects on human health and the environment. Their toxicity also may affect microbe-mediated ecological processes, seriously compromising major biogeochemical cycles (Babich \& Stotzky, 1985), and larger organisms (Otachi et al., 2015; Plessl et al., 2017) including humans (e.g. Tchounwou et al., 2012). Weathering and human activities introduce trace metals into the hydrosphere all over the earth, but lacustrine sediments from locations under agricultural influence are the areas of highest risk to metal accumulation. While these types of pollution are important in saline lakes, the present work will focus on pollution by $\mathrm{N}$ compounds.

\section{NITROGEN CYCLING IN LAKES}

As previously stated, ecosystem productivity is driven by, among other factors, $\mathrm{N}$ availability. 
The largest $\mathrm{N}$ reservoir on Earth is the atmosphere where $\mathrm{N}$ is present in the form of the rater inert dinitrogen gas $\left(\mathrm{N}_{2}\right)$ (Ward, 2012). In aquatic ecosystems, $\mathrm{N}$ primarily occurs as $\mathrm{N}_{\text {org }}, \mathrm{NO}_{3}{ }^{-}$, and ammonium $\left(\mathrm{NH}_{4}{ }^{+}\right)$, the latter the most biologically available form that can be incorporated into biomolecules. The $\mathrm{N}$ cycle consists of a complex network of transformations that converts and transfers $\mathrm{N}$ among the reservoirs (Thamdrup, 2012). However, the anthropogenic increase in the $\mathrm{N}$ cycle in recent decades has reached a point where it can have adverse environmental consequences on a global scale (Battye et al., 2017). While extensive research has been carried out on $\mathrm{N}$ cycle in marine and freshwater ecosystems (e.g. Bowden, 1987; Voss et al., 2013), it has received scant attention in saline lakes.

Nitrogen fixation is an important source of "new" N, performed by prokaryotes (bacteria and archaea) when converting $\mathrm{N}_{2}$ to $\mathrm{NH}_{4}^{+}$(Fig. 1). In aquatic ecosystems, among the main N-fixers are cyanobacteria and anaerobes, including methanogens, sulfate $\left(\mathrm{SO}_{4}{ }^{2-}\right)$ reducers, and fermenters. Nevertheless, most organisms cannot fix $\mathrm{N}_{2}$ directly, but rather obtain it as $\mathrm{NH}_{4}{ }^{+}$from the environment (ammonium assimilation), or by reducing $\mathrm{NO}_{3}^{-}$to $\mathrm{NH}_{4}^{+}$(nitrate assimilation). Certain microorganisms can use $\mathrm{NH}_{4}^{+}$not only for building biomass, but also for gaining energy during the nitrification process (Canfield et al., 2005). Nitrification involves the transformation of $\mathrm{NH}_{4}+$ to hydroxylamine $\left(\mathrm{NH}_{2} \mathrm{OH}\right)$, which is subsequently oxidized to nitrite $\left(\mathrm{NO}_{2}{ }^{-}\right)$, and further oxidized to $\mathrm{NO}_{3}{ }^{-}$. Nitrification is also a significant source of atmospheric $\mathrm{N}_{2} \mathrm{O}$, because this greenhouse gas is formed as a by-product during the process (Bremner \& Blackmer, 1978; Dore et al., 1998).

When $\mathrm{O}_{2}$ is limited or unavailable, microorganisms can dissimilatorily reduce $\mathrm{NO}_{3}{ }^{-}$to either a gaseous product $\left(\mathrm{N}_{2}\right.$ or $\left.\mathrm{N}_{2} \mathrm{O}\right)$ or $\mathrm{NH}_{4}+$ to obtain energy. Reduction of $\mathrm{NO}_{3}{ }^{-}$is usually coupled to organic $\mathrm{C}$ oxidation driven by facultative anaerobic heterotrophs. However, some dissimilatory $\mathrm{NO}_{3}{ }^{-}$reducers are chemolithoautotrophs and are able to oxidize reduced inorganic compounds such as hydrogen gas $\left(\mathrm{H}_{2}\right)$, hydrogen sulfide $\left(\mathrm{H}_{2} \mathrm{~S}\right)$, or $\mathrm{NH}_{4}{ }^{+}$. The first step in dissimilatory $\mathrm{NO}_{3}{ }^{-}$reduc-

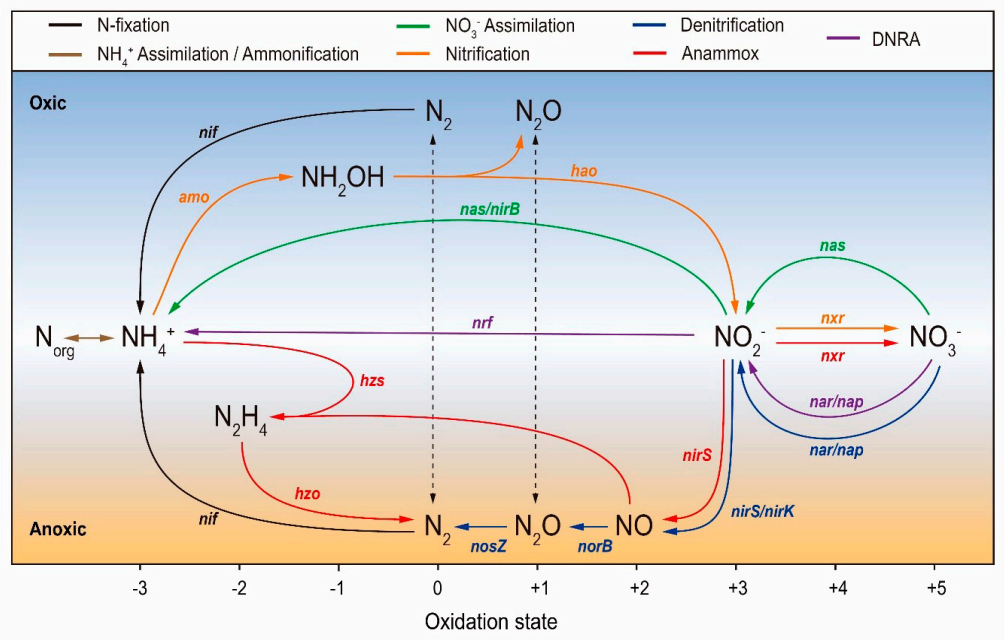

Figure 1. Schematic representation of the major microbial pathways in the nitrogen cycle. Aerobic and anaerobic processes are differentiated by background colors. Genes encoding enzymes that catalyze each step in the pathway include in italics. Dashed vertical lines indicate the contribution to atmospheric loading of gaseous nitrogen compounds. DNRA: dissimilatory nitrate reduction to ammonium. (Adapted from Hallin et al., 2017). Representación esquemática de los principales procesos microbianos del ciclo del nitrógeno. Los procesos aeróbicos y anaeróbicos están diferenciados por los colores de fondo. Los genes que codifican las enzimas que catalizan cada paso de la vía se incluyen en cursiva. Las líneas verticales discontinuas indican las emisiones de los compuestos nitrogenados gaseosos. DNRA: reducción disimilatoria de nitrato a amonio. (Adaptado de Hallin et al., 2017). 
tion is the conversion of $\mathrm{NO}_{3}{ }^{-}$to $\mathrm{NO}_{2}^{-}$. Depending on the product formed by $\mathrm{NO}_{2}{ }^{-}$reduction, three main pathways can be distinguished: (1) denitrification is the process of reducing $\mathrm{NO}_{2}{ }^{-}$ to form $\mathrm{N}_{2}$, and $\mathrm{N}_{2} \mathrm{O}$ as by-product (Knowles, 1982); (2) anaerobic ammonium oxidation (anammox), the process by which $\mathrm{NO}_{2}-$ reduction is coupled to $\mathrm{NH}_{4}{ }^{+}$oxidation to produce $\mathrm{N}_{2}$ (Jetten et al., 1998); (3) dissimilatory nitrate reduction to ammonium (DNRA), when the reduction of $\mathrm{NO}_{2}{ }^{-}$yields $\mathrm{NH}_{4}{ }^{+}$(Tiedje, 1988).

Denitrification is a major sink in the $\mathrm{N}$ cycle and is considered the main $\mathrm{NO}_{3}^{-}$reduction process in aquatic environments (Piña-Ochoa \& Álvarez-Cobelas, 2006). This pathway is driven by facultative anaerobes, which are mainly limited by the availability of electron donors (Korom, 1992; Rivett et al., 2008), and is not affected by salinity (Arce et al., 2014). This form of microbial respiration reduces sequentially $\mathrm{NO}_{3}-$ to $\mathrm{NO}_{2}{ }^{-}$, nitric oxide (NO), $\mathrm{N}_{2} \mathrm{O}$ and $\mathrm{N}_{2}$. Denitrifiers can obtain metabolic energy from: (1) oxidation of organic compounds (chemoorganotrophic heterotrophs); (2) oxidation of inorganic compounds, such as reduced inorganic $\mathrm{S}$ forms (chemolithotrophic autotrophs). Complete denitrification of $\mathrm{NO}_{3}-$ to $\mathrm{N}_{2}$ requires the four partly independent respiratory processes to be activated simultaneously (Zumft, 1997). Otherwise, intermediates can be formed, leading to effects such as the emission of $\mathrm{N}_{2} \mathrm{O}$ emission to the atmosphere.

Anammox is also a major microbial pathway for $\mathrm{N}$ removal in aquatic environments. This pathway is carried out by autotrophic facultative anaerobic bacteria. The metabolic pathway for anammox presumably involves the reduction of the electron acceptor $\left(\mathrm{NO}_{2}^{-}\right)$to $\mathrm{NO}$, which reacts with the electron donor $\left(\mathrm{NH}_{4}{ }^{+}\right)$to form the intermediate hydrazine $\left(\mathrm{N}_{2} \mathrm{H}_{4}\right)$, and subsequently is oxidized to $\mathrm{N}_{2}$. These microorganisms were firstly identified in wastewater treatment systems (Mulder et al., 1995; Van de Graaf et al., 1995), but have more recently also been found in aquatic environments (Kuypers et al., 2003). While N2 is the most prevalent end-product of anammox, about $20 \%$ of consumed $\mathrm{NO}_{2}{ }^{-}$is oxidized to $\mathrm{NO}_{3}{ }^{-}$as a by-product when reducing equivalents are needed for $\mathrm{CO}_{2}$ fixation (Van de Graaf et al., 1997).
In aquatic ecosystems, DNRA is another important pathway of $\mathrm{NO}_{3}{ }^{-}$removal (Burgin \& Hamilton, 2007; Giblin et al., 2013). During DNRA, $\mathrm{NO}_{3}{ }^{-}$is reduced to $\mathrm{NO}_{2}{ }^{-}$, which subsequently is directly reduced to $\mathrm{NH}_{4}{ }^{+}$without producing any intermediate $\mathrm{N}$ compound. DNRA retains $\mathrm{N}$ in the system as $\mathrm{NH}_{4}{ }^{+}$, which is more biologically reactive than $\mathrm{NO}_{3}{ }^{-}$. This pathway can be performed by both, chemoorganotrophic heterotrophs, which use organic compounds as the electron donor (fermentative DNRA), and chemolithotrophic autotrophs, which oxidize inorganic compounds such as sulfides. Organisms capable of carrying out DNRA are strict anaerobes (Hill, 1996), and recent studies suggest their role in $\mathrm{N}_{2} \mathrm{O}$ consumption (Hallin et al., 2017).

\section{BIOGEOCHEMICAL PROCESSES IN AQUATIC ECOSYSTEMS}

As was mentioned in the previous section, microorganisms can reduce and oxidize $\mathrm{N}$ compounds to gain energy. However, such energy can be also obtained from redox reactions associated with other biogeochemical cycles including those of $\mathrm{C}, \mathrm{S}$ or Fe. These cycles are common and essential in aquatic ecosystems (fresh and saline), as microbial activity degrades DOM used as electron donors. Many prokaryotes can grow in the absence of $\mathrm{O}_{2}$, being either facultative or strict anaerobes, depending on whether they tolerate certain oxic conditions. Therefore, these microorganisms are able to survive in anoxic environments like lacustrine sediments or bottom layer from meromictic lakes.

One of the most successful strategies is the heterotrophic metabolism, which is based on the mineralization of organic material by coupling the oxidation of organic $\mathrm{C}$ to the reduction of terminal electron acceptors (e.g. $\mathrm{NO}_{3}{ }^{-}$). While organic matter is the largest electron donor for redox reactions, microorganisms use the terminal electron acceptors with the highest tendency to be reduced (i.e. reduction potential) following a redox reaction sequence (Stumm \& Morgan, 1981). This constitutes a first principle in understanding energy and matter transformations in ecosystems. The thermodynamic sequence starts using $\mathrm{O}_{2}$ as electron acceptor, followed by $\mathrm{NO}_{3}{ }^{-}$, Mn oxides, 


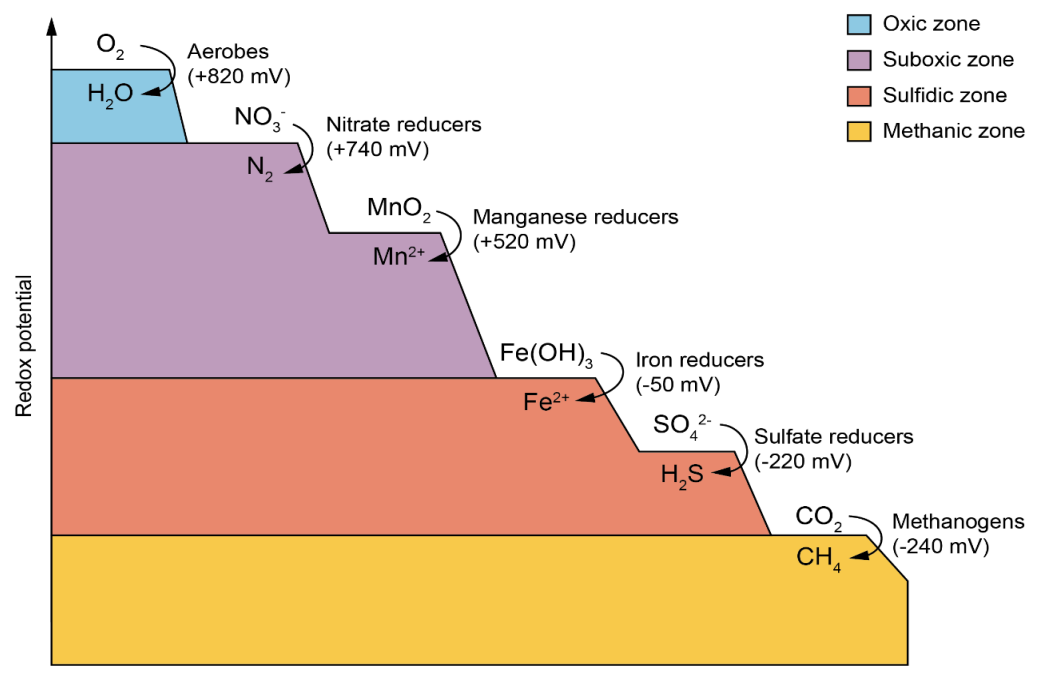

Figure 2. Sequence of microbially mediated redox reactions in natural systems. The more positive the redox potential, the more energy is released per electron transferred. (Adapted from Weiner, 2012). Secuencia de reacciones redox mediadas por microorganismos en sistemas naturales. Cuanto más positivo es el potencial redox, más energía se libera por cada electrón transferido. (Adaptado de Weiner, 2012).

Fe oxides, $\mathrm{SO}_{4}{ }^{2-}$, and $\mathrm{CO}_{2}$ in the different redox zones (Fig. 2). Thermodynamic imbalance is observed when a flux of organic carbon introduces energy to the system, fueling biogeochemical turnover. Then, a vertical succession of redox reactions is driven by microbial respiration beyond oxic-anoxic interfaces (e.g. water-sediment interface). The source of most terminal electron acceptors is the oxic zone. Some of them $\left(\mathrm{NO}_{3}{ }^{-}\right.$, $\mathrm{O}_{2}, \mathrm{SO}_{4}{ }^{2-}$ ) can diffuse into the anoxic zone from the water column, whereas others are regenerated at the oxic-anoxic interface due to oxidation (e.g. $\mathrm{NH}_{4}{ }^{+}$) (Mermillod-Blondin, 2011).

As discussed above, $\mathrm{N}$ may have a high availability due to salinity. However, S also plays a key role in saline lakes, where high concentrations of $\mathrm{SO}_{4}{ }^{2-}$ are often found. In such environments, S cycling occurs at the boundary layer of the sediment-water interface, where S-compounds interact with the biogeochemical cycling of other elements such as C, O, N, and Fe (Jørgensen, 1982; Thamdrup et al., 1994, Canfield \& Farquhar, 2012). Dissimilatory sulfate reduction is the primary driver of the biogeochemical cycling of S in sediments (Jørgensen, 1982; Canfield \& Farquhar, 2012; Wasmund et al., 2017).
During sulfate reduction, $\mathrm{SO}_{4}{ }^{2-}$ acts as an electron acceptor to produce $\mathrm{H}_{2} \mathrm{~S}$, which is generally coupled to the oxidation of organic compounds. These compounds include a great variety of electron donors, such as hydrocarbons, organic acids, alcohols, sugars, and aromatic compounds. For this reason, the $\mathrm{S}$ cycle is of major importance to remove organic pollutants in saline environments.

Redox reactions play a major role at aquatic interfaces, which are hot spots of biodiversity, nutrient turnover and pollutants removal (Krause et al., 2017; Lau et al., 2018). Biogeochemical cycling is associated with interfaces between compartments of aquatic environments with sharp gradients, like found in saline lakes when brine waters meet freshwater from the underlying aquifer (freshwater-saltwater interface; FSI). In addition, both saline and freshwater ecosystems are characterized by an oxic-anoxic interface within the sediment (sediment-water interface, SWI). The depth of this interface depends on the input of degradable organic matter to the sediment. In systems with high primary productivity (e.g. eutrophic lakes), $\mathrm{O}_{2}$ transport is controlled by molecular diffusion and oxygen cannot penetrate more than a few mm (Brune et al., 2000) into the 
sediment, where prokaryotes (Bacteria and Archaea) are often abundant. These microorganisms are essential for the ecosystem functioning, as they are at the bottom of the food web. In saline lakes, those are adapted to life at high salt concentrations (up to about $350 \%$ ) and to the high osmotic pressure due to the high salinity (Oren, 2013). Depending on the relationship between these microorganisms and salt, they may range from halotolerant (non-halophile but tolerate salt) to extreme halophiles (grow best in hypersaline media). However, saline lakes are often located in arid areas and/or have alkaline conditions. Thus, it is common to find poly-extremophiles in such systems that show not only halophilic, but also alkaliphilic and/or thermophilic properties (Seckbach \& Rampelotto, 2015). Two main strategies are used by halophilic and halotolerant prokaryotes to deal with the osmotic stress in highly saline environments: i) to accumulate high concentrations of inorganic ions in the cytoplasm; ii) to prevent high salt concentrations from reaching the cytoplasm. While the first strategy requires the adaptation of the whole intracellular machinery to the presence of high ionic concentrations, it is much less costly than the second, which involves the use of organic compatible solutes produced by the cells to maintain the osmotic equilibrium. Therefore, there are many metabolic processes identified in freshwater lakes that can also occur in saline lakes, and others that, due to their energetic cost, do not exist (i.e. autotrophic nitrification; Oren et al., 2013). For this reason, the study of microbial processes in saline lakes is of vital importance in order to discover metabolic pathways not described in freshwater systems.

\section{SALINE LAKES IN POLLUTION ATTENU- ATION}

As described above, aquatic interfaces play a key role in nutrient recycling. Understanding the link between groundwater and surface water in saline lakes will help to identify how pollutants can be removed when reaching these systems (Gómez-Alday et al, 2014). From a biogeochemical perspective, two main interfaces are present in discharge type saline lakes: (1) the sediment-water interface (SWI); (2) the freshwater-saltwater interface (FSI).
The interface between sediment and water is potentially the most important aquatic interface for microbial turnover, because of the abundance of prokaryotes in sediments compared to the water column (Lau et al., 2018). Processes controlling nutrient recycling and pollutants removal at the SWI depend on the existing redox environments at the interface, which in turn affects the distribution of electron donors and acceptors. Moreover, the chemical composition of sediments will determine the predominance of microbial pathways. For instance, the organic C:N ratio of available substrates, which provides information about organic carbon availability, helps to predict the dominant $\mathrm{NO}_{3}{ }^{-}$removal pathway (Tiedje, 1983).

In contrast, the aquatic interface between freshwater and saltwater is not a sharp boundary but rather a transition zone. Under both, steadystate and unsteady-state conditions, the location, shape, and extent of the interface depends upon factors such as the hydrogeology of the aquifer, hydraulic gradients, climatic stresses (Sakr, 1999), and land uses (i.e. irrigation). Based on the redox state of both, the freshwater and the saltwater, different scenarios can be considered (Santoro, 2010): (1) oxic conditions in both freshwater and saltwater; (2) oxic freshwater meets anoxic saltwater; (3) anoxic conditions across the entire FSI. Anoxia derives from the microbial decomposition of OM, which is the main electron donor for biogeochemical processes. Thus, interfaces that are partly (Addy et al., 2005) or totally anoxic (Kroeger et al., 2007) show higher rates of nutrient recycling. Previous research has provided important information about the hydrogeochemical and biological processes that take place at these interfaces (Moore, 1999; Andersen et al., 2005; Humphreys et al., 2009), including those that involves nutrient recycling (Slomp \& Van Cappellen, 2004; Gonneea \& Charette, 2014; Couturier et al., 2017). Nevertheless, most of the studies on FSI concern coastal aquifers and very little is known about these in saline lakes.

In saline lake-aquifer systems, the distribution is typically the opposite of that found in coastal aquifers: the brine is located at the top and the freshwater aquifer below. Recent attention has been focused on evaluating the distribution of the FSI in saline lakes associated to hydrogeological 


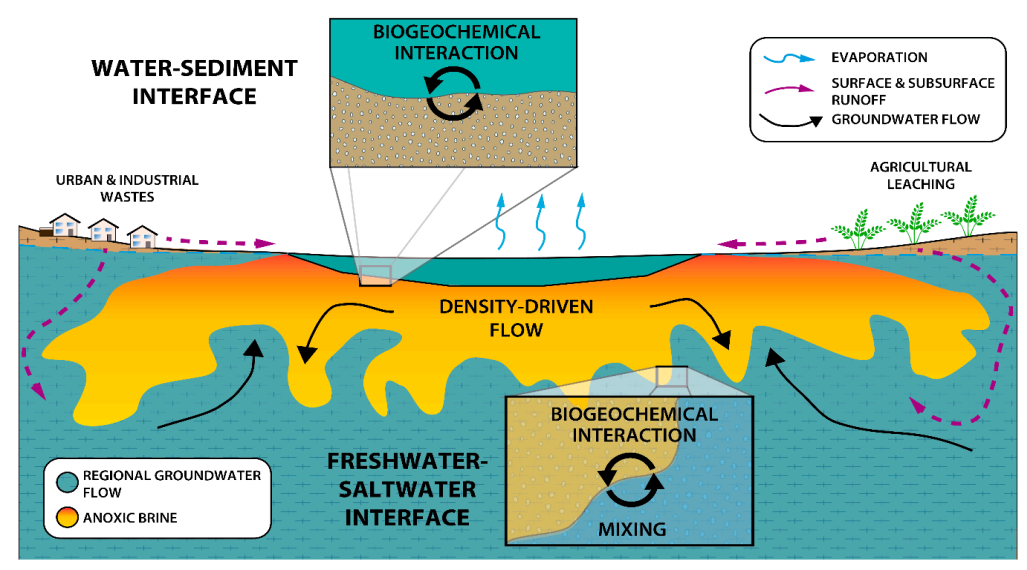

Figure 3. Conceptual model (longitudinal section) of hydrodynamic transport by density-driven flow across the freshwater-saltwater interface in a discharge terminal saline lake (not to scale). Modelo conceptual (sección longitudinal) del transporte hidrodinámico por flujo de densidad a través de la interfase agua dulce-agua salada en un lago salado terminal de descarga (no a escala).

processes (Yechieli \& Wood, 2002; Lee et al., 2014; Amiri et al., 2016; Bentley et al., 2016) and to microbially mediated processes (Avrahamov et al., 2014; Carrey et al., 2013; Gómez-Alday et al., 2014; Lewandowski et al., 2015; Valiente et al., 2018). In such systems, nutrient recycling depends on solute transport by density-driven flow (DDF) and further diffusion from the surface lake water to deeper zones of the aquifer through the FSI (Fig. 3). The DDF is the result of the difference in density between brine in saline lakes and fresh groundwater (Zimmermann et al., 2006). Solutes, including pollutants and oxidable organic matter, can enter into lakes through precipitation, surface runoff (e.g. irrigation returns and wastewater spills), and groundwater. Therefore, understanding the role of the FSI in nutrient recycling is essential to comprehend hydrogeological processes in saline lakes because biogeochemical processes control the chemical evolution of lakes and the groundwater of the connected aquifer (Castanier et al., 1993; Skidmore et al., 2010).

\section{MULTIDISCIPLINARY APPROACH: FROM FIELDWORK TO LABORATORY ANALYSIS}

The existing literature on the study of saline lakes is extensive and focuses particularly on classical limnological studies to address human impacts (Stenger-Kovács et al., 2014; Ogato et al., 2015; Stenger-Kovács et al., 2018; Şuteu et al., 2021). Also, several studies have focused on the geochemical aspects of saline lakes in connection with such impacts (Stojanovic et al., 2009; Boros et al., 2017; Corrales-González et al., 2019; Kolpakova et al., 2019; among others). Others have highlighted the relevance of microorganisms in saline lakes, with a sharp increase over in the last years, as new analytical methodologies have been developed (Post, 1977; Abed et al., 2012; Casamayor et al., 2013; Grant \& Jones, 2016; among others). Finally, the special features of saline lakes compared to freshwater lakes have led to a large number of studies on the hydrogeological functioning of these lakes (Yechieli, 1993; Wooding et al., 1997; Rodríguez-Rodríguez, 2007; Gómez-Alday et al., 2014). To provide a comprehensive solution to anthropogenic pollution in such ecosystems, here we aim at the integration of skills from different disciplines, as summarized in Figure 4. In addition, the analytical methodologies cited throughout this section are summarized in Table 2.

As stated above, the chemical characterization is an essential factor in the study of saline lakes, not only to know the fate of pollutants but also to estimate the mass balance of solutes. Phys- 


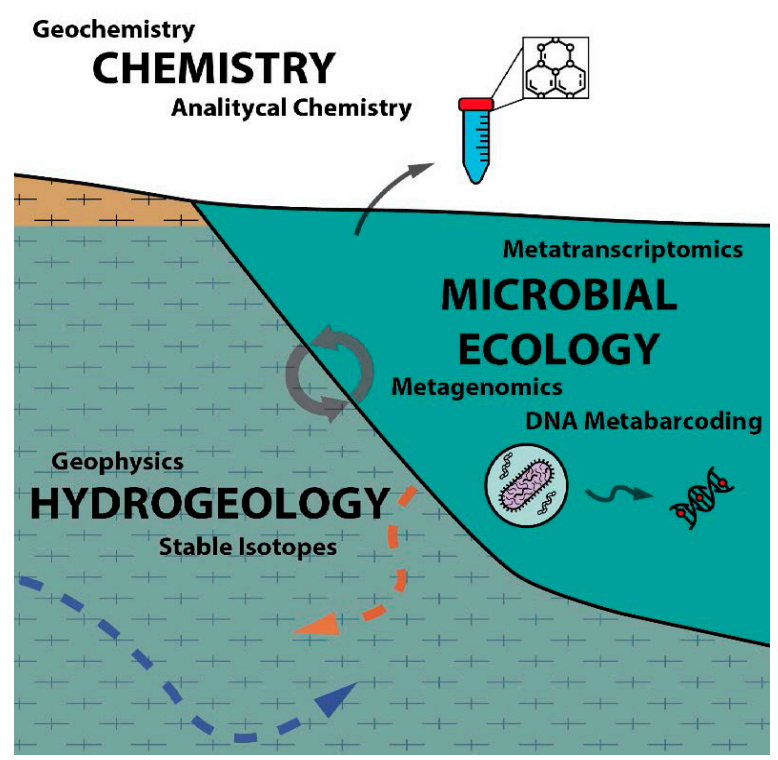

Figure 4. Conceptual scheme showing the integration of methodologies from the fields of chemistry, microbial ecology and hydrogeology into a common approach to address pollution attenuation in saline lakes. Esquema conceptual que muestra la integración de metodologías provenientes de los campos de la química, la ecología microbiana y la hidrogeología en un enfoque común para abordar el estudio de la atenuación de la contaminación en los lagos salados.

ical-chemical parameters provide information about water quality and redox conditions. These parameters can include water temperature $(\mathrm{T})$, $\mathrm{pH}$, redox potential (Eh), dissolved oxygen (DO), electrical conductivity (EC) and total dissolved solids (TDS), the latter two being good proxies for estimating the salinity of the system. Organic $\mathrm{C}$ and $\mathrm{N}$, defined as organically bound $\mathrm{C}$ and $\mathrm{N}$ in organic compounds under various oxidation states, are routinely determined by high-temperature catalytic combustion and chemiluminescence detection (CL). Depending on whether the analyzed sample is filtered or not, it refers to total organic C (TOC) and N (TON), or dissolved organic $\mathrm{C}$ (DOC) and $\mathrm{N}$ (DON). To establish the chemical composition of water solutions, a variety of analytical techniques are available. Major anions $\left(\mathrm{HCO}_{3}{ }^{-} / \mathrm{CO}_{3}{ }^{2-}, \mathrm{Cl}^{-}\right.$, and $\left.\mathrm{SO}_{4}{ }^{2-}\right)$ and cations $\left(\mathrm{K}^{+}, \mathrm{Na}^{+}, \mathrm{Ca}^{2+}\right.$, and $\left.\mathrm{Mg}^{2+}\right)$ provide valuable information about the geochemical-water type, mineral solubility and salinity source.
Except for alkalinity, usually determined by titration, separation techniques are widely used to quantify major ions. These separation techniques include, among others, ion chromatography (IC) or capillary electrophoresis (CE). Inductively coupled plasma optical emission spectrometry (ICP-OES) and atomic absorption spectroscopy (AAS) are commonly used for inorganic trace elements analysis (e.g. metals). However, other techniques can be used depending on several factors including instrument availability, ease of use, interferences, elements of interest, and the range of elemental concentrations expected. Among these techniques, graphite furnace atomic absorption (GF-AAS), inductively coupled plasma mass spectrometry (ICP-MS) and total X-ray fluorescence spectroscopy (TXRF) deserve special mention (Plessl et al., 2017). For organic pollutants, gas chromatography combined with mass spectrometers (GC-MS) under different configurations is the most common technique (Menchén et al., 2020). Finally, concentrations of dissolved gases of relevance in the main biogeochemical cycles such as $\mathrm{CO}_{2}$, methane $\left(\mathrm{CH}_{4}\right)$ and $\mathrm{N}_{2} \mathrm{O}$ are usually determined using the headspace equilibration method and further GC under different configurations (Yang et al., 2015; León-Palmero et al., 2020)

The main drawback of separation techniques in saline water analysis is often the required dilution of the sample, to avoid saturation of the column, resulting in the lack of resolution for compounds in lower concentrations. For elements such as arsenic (As), selenium (Se), and $\mathrm{Hg}$, cold vapour atomic absorption spectrometry (CV-AAS) is widely used. For N-derived species, the most suitable methods are based on spectrophotometry, adapted from marine water analysis (García-Robledo et al., 2014; Valiente et al., 2019). To determine $\mathrm{NO}_{2}{ }^{-}$and $\mathrm{NO}_{3}{ }^{-}$, the Griess assay with further reduction is widely used is widely used for its simplicity, promptness and low price. For the same reason, the indophenol blue method based on the Berthelot reaction has been standardized for $\mathrm{NH}_{4}^{+}$quantification. The above-described techniques can also be used to analyze pore water. For this reason, the development of high-resolution electrochemical techniques has enabled monitoring chemical microenvironments in sed- 
iments with minimum disturbance (Revsbech \& Jørgensen, 1986). These microelectrodes are used for the analysis of selective ions (e.g. $\mathrm{Na}^{+}, \mathrm{Ca}^{2+}$ ), but also for physical-chemical parameters (e.g. $\mathrm{pH}, \mathrm{Eh})$ and biogeochemical compounds of interest (e.g. $\mathrm{O}_{2}, \mathrm{H}_{2} \mathrm{~S}, \mathrm{~N}_{2} \mathrm{O}$ ).

Table 2. Summary of analytical methods described in the present work. CL: chemiluminescence detection. UV-VIS: ultraviolet-visible spectroscopy. IC: ion chromatography. CE: capillary electrophoresis. AAS: atomic absorption spectroscopy. ICP-OES: inductively coupled plasma optical emission spectrometry. GF-AAS: graphite furnace atomic absorption. ICPMS: inductively coupled plasma mass spectrometry. TXRF: total X-ray fluorescence spectroscopy. CV-AAS: cold vapour atomic absorption spectrometry. GC-FID: gas chromatography with flame-ionization detection. GC-TCD: gas chromatography with thermal conductivity detector. GC-MS: gas chromatography with mass spectrometry. IRMS: isotope-ratio mass spectrometry. ERT: electrical resistivity tomography. Resumen de los métodos analíticos descritos en el presente trabajo. CL: detección por quimioluminiscencia. UV-VIS: espectroscopia ultravioleta-visible. CI: cromatografía iónica. CE: electroforesis capilar. AAS: espectroscopia de absorción atómica. ICP-OES. espectrometría de emisión óptica por plasma acoplado inductivamente. GF-AAS: absorción atómica en horno de grafito. ICP-MS: espectrometría de masas con plasma acoplado inductivamente. TXRF: espectroscopia de fluorescencia total de rayos $X$. CV-AAS: espectrometría de absorción atómica de vapor frío. GC-FID: cromatografia de gases con detección por ionización de llama. GC-TCD: cromatografia de gases con detector de conductividad térmica. GC-MS: cromatografía de gases con espectrometría de masas. IRMS: espectrometría de masas de relación isotópica. ERT: tomografía de resistividad eléctrica.

\begin{tabular}{ll}
\hline Parameters & Description/materials \\
\hline Physical-chemical & In situ using portable probes, microelectrodes \\
TOC/DOC & High-temperature catalytic combustion \\
TON/DON & CL \\
$\mathrm{NO}_{3}{ }^{-}, \mathrm{NO}_{2}{ }^{-}, \mathrm{NH}_{4}{ }^{+}$ & UV-VIS coupled to Griess and Berthelot assays \\
Alkalinity & Acidimetric titration \\
Major anions & IC, CE \\
Major cations & IC, AAS, ICP-OES \\
Trace elements & ICP-OES, GF-AAS, ICP-MS, TXRF, CV-AAS \\
Gases & GC-FID, GC-TCD, microelectrodes \\
Organic pollutants & GC-MS \\
Stable isotopes & IRMS \\
Taxonomic diversity & DNA metabarcoding \\
Functional diversity & Metagenomics \\
Groundwater resistivity & ERT \\
\hline
\end{tabular}

Recently, multi-stable isotope approaches $(\delta \mathrm{D}$, $\left.\delta^{13} \mathrm{C}, \delta^{15} \mathrm{~N}, \delta^{18} \mathrm{O}, \delta^{34} \mathrm{~S}\right)$ have been used, coupled to hydrochemistry, to identify pollution sources and mitigation pathways in groundwater (Puig et al., 2013; Hosono et al., 2014; Margalef-Marti et al., 2019; Paredes et al., 2020), including saline systems (Gómez-Alday et al., 2014; Valiente et al., 2018; 2020). Microbial-mediated redox reactions are associated with a certain kinetic isotopic fractionation that varies in magnitude depending on reaction rates, concentrations of products and reactants, environmental conditions, and microorganisms responsible for the reaction. These processes include those previously mentioned like denitrification, DNRA or dissimilatory sulfate reduction. Assuming that the substrate concentration is high enough that the isotopic composition of the reservoir is insignificantly changed by the reaction, Rayleigh distillation models can be applied to calculate the amount of isotope fractionation (Mariotti et al., 1981; Carrey et al., 2013). In addition to biogeochemical tracing, stable isotopes can be used to identify the origin and fate of contaminants in the environment. Isotopic signatures from different sources (natural soil, minerals, fertilizers, or sewage) are usually measured by Isotope Ratio Mass Spectrometer (IRMS) and can be used for tracing single and multi-pollutant contaminations (Vitòria et al., 2004). In addition, the use of water stable isotopes $(\delta \mathrm{D}$ and $\delta 18 \mathrm{O})$ is particularly useful for studying recharge processes in aquifers where freshwater and saltwater confluence (Cendón et al., 2010). Stable isotopes are also used to quantify $\mathrm{N}$ recycling processes. In that sense, the isotope pairing technique (IPT) is a well-established tool based on the addition of labeled substrate (e.g. ${ }^{15} \mathrm{NO}_{3}{ }^{-}$) in water-sediment incubations (Nielsen, 1992). During the last decades, this technique has been widely applied to a variety of aquatic ecosystems to measure denitrification, DNRA, and anammox (RisgaardPetersen et al., 2003; Trimmer et al., 2006; Welti et al., 2012; Song et al., 2016; Salk et al., 2017).

Returning to the role of microorganisms in biogeochemical cycles, the implementation of molecular biology techniques was a revolution in the field of microbial ecology. Traditionally, cultures have been used to characterize bacteria, enabling a wide range of biochemical and physiological 
tests. Nonetheless, the vast majority of bacteria cannot be cultivated using standard techniques. Molecular biology techniques enabled studying non-cultivable species, avoiding the problem of isolating the different species by growth condition preferences. These techniques require collecting and extracting environmental DNA (eDNA) for further analysis, such as gene amplification/ quantification or high-throughput sequencing (HTSeq). For taxonomic and phylogenetic purposes, certain pretty stable rRNA genes are used as targets (e.g. 16S rRNA for prokaryotes, $18 \mathrm{~S}$ rRNA for eukaryotes). This barcoding approach is called "amplicon sequencing" and yields much information about microbial abundance in complex communities (Kirchman, 2018). Despite their great usefulness, a high percentage of taxa are still unknown and therefore we are not taking full advantage of these techniques (Zamkovaya et al., 2020), especially in extreme environments such as saline lakes where microbial communities evolve so quickly (Li et al., 2014). To unravel the functional potentials (DNA-based) and functional activities (RNA-based) within diverse environmental samples, whole metagenome shotgun sequencing based in DNA (metagenomics) and RNA (metatranscriptomic) approaches are used. The first one has been used not only to identify organisms performing specific steps in biogeochemical processes, but also to suggest new metabolic pathways (Peura et al., 2015). The latter has been used to confirm which genes are expressed and whether certain functions are actually occurring in the environment (Berg et al., 2018). Combined, these approaches are a powerful tool for exploring the biogeochemical role of microbes in saline lakes.

Finally, in saline lake-aquifer systems (i.e. terminal discharge lakes) the geometry of the DDF plays an important role in the transport of chemical species. In such systems, it is necessary to develop a conceptual hydrogeological model to understand how pollution attenuation occurs. For this purpose, a well-designed monitoring network (e.g. streams, wells, piezometers) helps to obtain data on water density and chemistry changes along flow lines. Among geophysical techniques, electrical resistivity tomography (ERT) is a more suitable method for visualizing spatial changes in the electrical conductivity (EC) over time to define the geometry of the FSI. This technique is based on 2D modelling of the ground resistivity using numerical techniques, either by finite elements or by finite differences.

\section{CONCLUSIONS}

Saline lakes are unique elements of the landscape, with extreme conditions that make them valuable habitats for biodiversity and particularly interesting from a biogeochemical perspective. However, they have historically been neglected and sometimes considered as disease-ridden wastelands, and nowadays they are still subject to numerous environmental impacts related to human activities. Their freshwater-saltwater interface provide them with a significant potential against one of these impacts: pollution. This interface is a hotspot for nutrient recycling, and therefore, to attenuate pollutants. In that sense, $\mathrm{NO}_{3}-$ is one of the main concerns of groundwater management in most of the world's agricultural areas. Investigating how saline lakes can attenuate this pollutant is a step forward in preserving the good ecological status of these ecosystems in a sustainable framework. In this overview, we emphasize that a wide range of techniques are required to solve the questions and new challenges that arise as we deepen our knowledge of their functioning. It requires the cooperation between specialists from different disciplines related to environmental sciences (limnology, hydrogeology, microbial ecology, chemistry...), as stated in the previous section (Figure 4). The results obtained through this approach allow for improved decision-making in order to fulfill the requirements of the Water Framework Directive. The integration of geophysical, hydrochemical, multi-isotopic and eDNA techniques in order to better understand how saline lakes act as reactive barriers for pollution represents a departure from the standard approach.

\section{ACKNOWLEDGMENTS}

We are thankful to the Iberian Association of Limnology (AIL) for the award to the best Iberian doctoral thesis in limnology of the period 2018-19, and the opportunity to disseminate the 
results through this manuscript. Special thanks to David Sanz, Santiago Castaño, Dioni Cendón and Michael Schagerl for their comments on previous works leading to the preparation of this paper, as well as to the colleagues from the Biotechnology \& Natural Resources Section (University of Castilla-La Mancha) and to the colleagues from the Environmental and Radiochemistry Group (University of Vienna) for their invaluable laboratory and field support. We thank Michael Stachowitsch for English copyediting and valuable comments. This work derived from the doctoral thesis written by Nicolas Valiente and funded by the doctoral grant BES-2012-052256 and the projects CGL2011-29975-C04-02 and CGL2017-87216-C4-2-R from the Spanish government, as well as PEIC-2014-004-P and SBPLY/17/180501/000296 projects from Castilla-La Mancha Regional Government.

\section{REFERENCES}

Abed, R. M. M., Ramette, A., Hübner, V., De Deckker, P. \& de Beer, D. (2012). Microbial diversity of eolian dust sources from saline lake sediments and biological soil crusts in arid Southern Australia. FEMS Microbiology Ecology, 80(2), 294-304. DOI: 10.1111/j.15746941.2011.01289.x

Addy, K., Gold, A., Nowicki, B., McKenna, J., Stolt, M. \& Groffman, P. (2005). Denitrification capacity in a subterranean estuary below a Rhode Island fringing salt marsh. Estuaries, 28(6), 896-908. DOI: 10.1007/BF02696018

Amiri, V., Nakhaei, M., Lak, R. \& Kholghi, M. (2016). Geophysical, isotopic, and hydrogeochemical tools to identify potential impacts on coastal groundwater resources from Urmia hypersaline Lake, NW Iran. Environmental Science and Pollution Research, 23(16), 1673816760. DOI: 10.1007/s11356-016-6859-y

Andersen, M. S., Nyvang, V., Jakobsen, R. \& Postma, D. (2005). Geochemical processes and solute transport at the seawater/freshwater interface of a sandy aquifer. Geochimica et Cosmochimica Acta, 69(16), 3979-3994. DOI: $10.1016 /$ j.gca.2005.03.017

Arce, M. I., von Schiller, D. \& Gómez, R. (2014). Variation in nitrate uptake and denitrification rates across a salinity gradient in Mediterranean semiarid streams. Aquatic Sciences, 76(2), 295-311. DOI: 10.1007/s00027-014-0336-9

Argaman, E., Keesstra, S. D. \& Zeiliguer, A. (2012). Monitoring the impact of surface albedo on a saline lake in SW Russia. Land Degradation \& Development, 23(4), 398-408. DOI: 10.1002/1dr.2155

Avrahamov, N., Antler, G., Yechieli, Y., Gavrieli, I., Joye, S. B., Saxton, M., .... Sivan, O. (2014). Anaerobic oxidation of methane by sulfate in hypersaline groundwater of the Dead Sea aquifer. Geobiology, 12(6), 511528. DOI: 10.1111/gbi.12095

Babich, H. \& Stotzky, G. (1985). Heavy metal toxicity to microbe-mediated ecologic processes: A review and potential application to regulatory policies. Environmental Research, 36(1), 111-137. DOI: 10.1016/00139351(85)90011-8

Barbiero, L., Siqueira Neto, M., Braz, R. R., Carmo, J. B. do, Rezende Filho, A. T., Mazzi, E., .... Camargo, P. B. de. (2018). Biogeochemical diversity, O2-supersaturation and hot moments of GHG emissions from shallow alkaline lakes in the Pantanal of Nhecolândia, Brazil. Science of The Total Environment, 619620, 1420-1430. DOI: 10.1016/j.scitotenv. 2017.11.197

Battye, W., Aneja, V. P. \& Schlesinger, W. H. (2017). Is nitrogen the next carbon?. Earth's Future, 5(9), 894-904. DOI: 10.1002/ 2017EF000592

Bentley, L. R., Hayashi, M., Zimmerman, E. P., Holmden, C. \& Kelley, L. I. (2016). Geologically controlled bi-directional exchange of groundwater with a hypersaline lake in the Canadian prairies. Hydrogeology Journal, 24(4), 877-892. DOI: 10.1007/s10040-016-1368-0

Berg, C., Dupont, C. L., Asplund-Samuelsson, J., Celepli, N. A., Eiler, A., Allen, A. E., .... Ininbergs, K. (2018). Dissection of Microbial Community Functions during a Cyanobacterial Bloom in the Baltic Sea via Metatranscriptomics. Frontiers in Marine Science, 5, 55. DOI: $10.3389 /$ fmars.2018.00055

Boros, E., Jurecska, L., Tatár, E., Vörös, L. \& Kolpakova, M. (2017). Chemical composition and trophic state of shallow saline steppe lakes 
in central Asia (North Kazakhstan). Environmental Monitoring and Assessment, 189(11), 546. DOI: 10.1007/s10661-017-6242-6

Bowden, W. B. (1987). The biogeochemistry of nitrogen in freshwater wetlands. Biogeochemistry, 4(3), 313-348. DOI: 10.1007/ BF02187373

Bremner, J. M. \& Blackmer, A. M. (1978). Nitrous Oxide: Emission from Soils During Nitrification of Fertilizer Nitrogen. Science, 199(4326), 295-296. DOI: 10.1126/science. 199.4326 .295

Bronk, D. A., Roberts, Q. N., Sanderson, M. P., Canuel, E. A., Hatcher, P. G., Mesfioui, R., .... Love, N. G. (2010). Effluent Organic Nitrogen (EON): Bioavailability and Photochemical and Salinity-Mediated Release. Environmental Science \& Technology, 44(15), 5830-5835. DOI: $10.1021 / \mathrm{es} 101115 \mathrm{~g}$

Brune, A., Frenzel, P. \& Cypionka, H. (2000). Life at the oxic-anoxic interface: Microbial activities and adaptations. FEMS Microbiology Reviews, 24(5), 691-710. DOI: 10.1016/ S0168-6445(00)00054-1

Burgin, A. J. \& Hamilton, S. K. (2007). Have we overemphasized the role of denitrification in aquatic ecosystems? A review of nitrate removal pathways. Frontiers in Ecology and the Environment, 5(2), 89-96. DOI: 10.1890/1540-9295(2007)5[89:HWOTRO] 2.0.CO;2

Camacho, A., Picazo, A., Rochera, C., Santamans, A. C., Morant, D., Miralles-Lorenzo, J. \& Castillo-Escrivà, A. (2017). Methane Emissions in Spanish Saline Lakes: Current Rates, Temperature and Salinity Responses, and Evolution under Different Climate Change Scenarios. Water, 9(9). DOI: 10.3390/w9090659

Canfield, D. E. (2005). Aquatic geomicrobiology. Elsevier.

Canfield, D. E. \& Farquhar, J. (2012). The Global Sulfur Cycle. In: A.H. Knoll, D.E. Canfield \& K.O. Konhauser (eds.). Fundamentals of Geobiology. (pp. 49-64). John Wiley \& Sons, Ltd. DOI: $10.1002 / 9781118280874 . c h 5$

Carrey, R., Otero, N., Soler, A., Gómez-Alday, J. J. \& Ayora, C. (2013). The role of Lower Cretaceous sediments in groundwater nitrate attenuation in central Spain: Column experi- ments. Applied Geochemistry, 32, 142-152. DOI: 10.1016/j.apgeochem.2012.10.009

Cartwright, I., Hall, S., Tweed, S. \& Leblanc, M. (2009). Geochemical and isotopic constraints on the interaction between saline lakes and groundwater in southeast Australia. Hydrogeology Journal, 17(8), 1991-2004. DOI: 10.1007/s10040-009-0492-5

Casamayor, E. O., Triadó-Margarit, X. \& Castañeda, C. (2013). Microbial biodiversity in saline shallow lakes of the Monegros Desert, Spain. FEMS Microbiology Ecology, 85(3), 503-518. DOI: 10.1111/1574-6941.12139

Castanier, S., Bernet-Rollande, M.-C., Maurin, A. \& Perthuisot, J.-P. (1993). Effects of microbial activity on the hydrochemistry and sedimentology of Lake Logipi, Kenya. In: S.H. Hurlbert (ed.). Saline Lakes V. (pp. 99-112). Springer Netherlands. DOI: 10.1007/978-94011-2076-0_7

Cendón, D. I., Larsen, J. R., Jones, B. G., Nanson, G. C., Rickleman, D., Hankin, S. I., .... Maroulis, J. (2010). Freshwater recharge into a shallow saline groundwater system, Cooper Creek floodplain, Queensland, Australia. Journal of Hydrology, 392(3-4), 150-163. DOI: 10.1016/j.jhydrol.2010.08.003

Corrales-González, M., Rochera, C., Picazo, A. \& Camacho, A. (2019). Effect of wastewater management on phosphorus content and sedimentary fractionation in Mediterranean saline lakes. Science of The Total Environment, 668, 350-361. DOI: 10.1016/j.scitotenv. 2019.02.371

Couturier, M., Tommi-Morin, G., Sirois, M., Rao, A., Nozais, C. \& Chaillou, G. (2017). Nitrogen transformations along a shallow subterranean estuary. Biogeosciences, 14(13), 3321-3336. DOI: 10.5194/bg-14-3321-2017

De Deckker, P. (1983). Australian salt lakes: Their history, chemistry, and biota - a review. Hydrobiologia, 105(1), 231-244. DOI: 10.1007/ BF00025191

Degermendzhy, A. G., Zadereev, E. S., Rogozin, D. Yu., Prokopkin, I. G., Barkhatov, Y. V., Tolomeev, A. P., .... Gulati, R. D. (2010). Vertical stratification of physical, chemical and biological components in two saline lakes Shira and Shunet (South Siberia, Russia). Aquat- 
ic Ecology, 44(3), 619-632. DOI: 10.1007/ s10452-010-9336-6

Dore, J. E., Popp, B. N., Karl, D. M. \& Sansone, F. J. (1998). A large source of atmospheric nitrous oxide from subtropical North Pacific surface waters. Nature, 396(6706), 63-66. DOI: $10.1038 / 23921$

Duarte, C. M., Prairie, Y. T., Montes, C., Cole, J. J., Striegl, R., Melack, J. \& Downing, J. A. (2008). $\mathrm{CO} 2$ emissions from saline lakes: A global estimate of a surprisingly large flux. Journal of Geophysical Research: Biogeosciences, 113(G4). DOI: 10.1029/2007JG000637

Dugan, H. A., Bartlett, S. L., Burke, S. M., Doubek, J. P., Krivak-Tetley, F. E., Skaff, N. K., .... Weathers, K. C. (2017). Salting our freshwater lakes. Proceedings of the National Academy of Sciences, 114(17), 4453. DOI: 10.1073/pnas.1620211114

Dumont, H. (1995). Ecocide in the Caspian Sea. Nature, 377(6551), 673-674. DOI: 10.1038/377673a0

Fraser, P. \& Chilvers, C. (1981). Health aspects of nitrate in drinking water. Science of The Total Environment, 18, 103-116. DOI: 10.1016/ S0048-9697(81)80053-8

García, C. M. \& Niell, F. X. (1993). Seasonal change in a saline temporary lake (Fuente de Piedra, southern Spain). Hydrobiologia, 267(1-3), 211-223. DOI: 10.1007/ BF00018803

García-Robledo, E., Corzo, A. \& Papaspyrou, S. (2014). A fast and direct spectrophotometric method for the sequential determination of nitrate and nitrite at low concentrations in small volumes. Marine Chemistry, 162, 30-36. DOI: 10.1016/j.marchem.2014.03.002

Giblin, A., Tobias, C., Song, B., Weston, N., Banta, G. \& Rivera-Monroy, V. (2013). The Importance of Dissimilatory Nitrate Reduction to Ammonium (DNRA) in the Nitrogen Cycle of Coastal Ecosystems. Oceanography, 26(3), 124-131. DOI: 10.5670/oceanog.2013.54

Gómez-Alday, J. J., Carrey, R., Valiente, N., Otero, N., Soler, A., Ayora, C., .... Cortijo, A. (2014). Denitrification in a hypersaline lakeaquifer system (Pétrola Basin, Central Spain): The role of recent organic matter and Cretaceous organic rich sediments. Science of The
Total Environment, 497-498, 594-606. DOI: 10.1016/j.scitotenv.2014.07.129

Gonneea, M. E. \& Charette, M. A. (2014). Hydrologic Controls on Nutrient Cycling in an Unconfined Coastal Aquifer. Environmental Science \& Technology, 48(24), 14178-14185. DOI: $10.1021 / \mathrm{es} 503313 \mathrm{t}$

Grant, W. D. (2004). Life at low water activity. Philosophical Transactions of the Royal Society of London. Series B: Biological Sciences, 359(1448), 1249-1267. DOI: 10.1098/rstb. 2004.1502

Grant, W. D. \& Jones, B. E. (2016). Bacteria, Archaea and Viruses of Soda Lakes. In: M. Schagerl (ed.). Soda Lakes of East Africa. (pp. 97-147). Springer International Publishing. DOI: 10.1007/978-3-319-28622-8_5

Gulis, G., Czompolyova, M. \& Cerhan, J. R. (2002). An Ecologic Study of Nitrate in Municipal Drinking Water and Cancer Incidence in Trnava District, Slovakia. Environmental Research, 88(3), 182-187. DOI: 10.1006/enrs. 2002.4331

Hallin, S., Philippot, L., Löffler, F. E., Sanford, R. A. \& Jones, C. M. (2018). Genomics and Ecology of Novel N2O-Reducing Microorganisms. Trends in Microbiology, 26(1), 4355. DOI: 10.1016/j.tim.2017.07.003

Hammer, U. T. (1981). Primary production in saline lakes: A review. In: W.D. Williams (ed.). Salt Lakes. (pp. 47-57). Springer Netherlands. DOI: 10.1007/978-94-009-8665-7_5

Hammer, U. T. (1986). Saline lake ecosystems of the world. Dr. W. Junk Publishers.

Hassani, A., Azapagic, A., D’Odorico, P., Keshmiri, A. \& Shokri, N. (2020). Desiccation crisis of saline lakes: A new decision-support framework for building resilience to climate change. Science of The Total Environment, 703, 134718. DOI: 10.1016/j.scitotenv. 2019.134718

Heidelberg, K. B., Nelson, W. C., Holm, J. B., Eisenkolb, N., Andrade, K. \& Emerson, J. B. (2013). Characterization of eukaryotic microbial diversity in hypersaline Lake Tyrrell, Australia. Frontiers in Microbiology, 4, 115. DOI: $10.3389 /$ fmicb.2013.00115

Hill, A. R. (1996). Nitrate Removal in Stream Riparian Zones. Journal of Environmen- 
tal Quality, 25(4), 743-755. DOI: 10.2134/ jeq1996.00472425002500040014x

Horne, A. J. \& Galat, D. L. (1985). Nitrogen fixation in an oligotrophic, saline desert lake: Pyramid Lake, Nevada. Limnology and Oceanography, 30(6), 1229-1239. DOI: 10.4319/ lo.1985.30.6.1229

Hosono, T., Lorphensriand, O., Onodera, S., Okawa, H., Nakano, T., Yamanaka, T., .... Taniguchi, M. (2014). Different isotopic evolutionary trends of $\delta 34 \mathrm{~S}$ and $\delta 18 \mathrm{O}$ compositions of dissolved sulfate in an anaerobic deltaic aquifer system. Applied Geochemistry, 46, 30-42. DOI: 10.1016/j.apgeochem.2014.04.012

Hossein Mardi, A., Khaghani, A., MacDonald, A. B., Nguyen, P., Karimi, N., Heidary, P., .... Sorooshian, A. (2018). The Lake Urmia environmental disaster in Iran: A look at aerosol pollution. Science of The Total Environment, 633, 42-49. DOI: 10.1016/j.scitotenv.2018.03.148

Hosseini-Moghari, S.-M., Araghinejad, S., Tourian, M. J., Ebrahimi, K. \& Döll, P. (2020). Quantifying the impacts of human water use and climate variations on recent drying of Lake Urmia basin: The value of different sets of spaceborne and in situ data for calibrating a global hydrological model. Hydrology and Earth System Sciences, 24(4), 1939-1956. DOI: 10.5194/hess-24-1939-2020

Humphreys, W. F., Watts, C. H. S., Cooper, S. J. B. \& Leijs, R. (2009). Groundwater estuaries of salt lakes: Buried pools of endemic biodiversity on the western plateau, Australia. Hydrobiologia, 626(1), 79-95. DOI: 10.1007/ s10750-009-9738-4

Jankowski, J. \& Jacobson, G. (1989). Hydrochemical evolution of regional groundwaters to playa brines in central Australia. Journal of Hydrology, 108, 123-173. DOI: 10.1016/0022-1694(89)90281-3

Jetten, M. S. M., Strous, M., van de Pas-Schoonen, K. T., Schalk, J., van Dongen, U. G. J. M., van de Graaf, A. A., .... Kuenen, J. G. (1998). The anaerobic oxidation of ammonium. FEMS Microbiology Reviews, 22(5), 421-437. DOI: 10.1111/j.1574-6976.1998.tb00379.x

Jirsa, F., Gruber, M., Stojanovic, A., Omondi, S. O., Mader, D., Körner, W. \& Schagerl, M. (2013). Major and trace element geochemis- try of Lake Bogoria and Lake Nakuru, Kenya, during extreme draught. Geochemistry, 73(3), 275-282. DOI: 10.1016/j.chemer.2012.09.001 Jones, B. E., Grant, W. D., Duckworth, A. W. \& Owenson, G. G. (1998). Microbial diversity of soda lakes. Extremophiles, 2(3), 191-200. DOI: $10.1007 / \mathrm{s} 007920050060$

Jørgensen, B. B. (1982). Mineralization of organic matter in the sea bed-The role of sulphate reduction. Nature, 296(5858), 643-645. DOI: 10.1038/296643a0

Joye, S. B., Connell, T. L., Miller, L. G., Oremland, R. S. \& Jellison, R. S. (1999). Oxidation of ammonia and methane in an alkaline, saline lake. Limnology and Oceanography, 44(1), 178-188. DOI: 10.4319/1o.1999.44.1.0178

Joye, S. B. \& Hollibaugh, J. T. (1995). Influence of Sulfide Inhibition of Nitrification on Nitrogen Regeneration in Sediments. Science, 270(5236), 623-625. DOI: 10.1126/science. 270.5236 .623

Kempe, S., Kazmierczak, J., Landmann, G., Konuk, T., Reimer, A. \& Lipp, A. (1991). Largest known microbialites discovered in Lake Van, Turkey. Nature, 349(6310), 605-608. DOI: $10.1038 / 349605 \mathrm{a} 0$

Kirchman, D. L. (2018). Processes in microbial ecology (Second edition). Oxford University Press.

Knowles, R. (1982). Denitrification. Microbiological Reviews, 46(1), 43-70.

Kolpakova, M. N., Gaskova, O. L., Naymushina, O. S., Karpov, A. V., Vladimirov, A. G. \& Krivonogov, S. K. (2019). Saline lakes of Northern Kazakhstan: Geochemical correlations of elements and controls on their accumulation in water and bottom sediments. Applied Geochemistry, 107, 8-18. DOI: 10.1016/j.apgeochem.2019.05.013

Korom, S. F. (1992). Natural denitrification in the saturated zone: A review. Water Resources Research, 28(6), 1657-1668. DOI: 10.1029/92WR00252

Krause, S., Lewandowski, J., Grimm, N. B., Hannah, D. M., Pinay, G., McDonald, K., .... Turk, V. (2017). Ecohydrological interfaces as hot spots of ecosystem processes. Water Resources Research, 53(8), 6359-6376. DOI: 10.1002/2016WR019516 
Kroeger, K. D., Swarzenski, P. W., Greenwood, Wm. J. \& Reich, C. (2007). Submarine groundwater discharge to Tampa Bay: Nutrient fluxes and biogeochemistry of the coastal aquifer. Marine Chemistry, 104(1-2), 85-97. DOI: 10.1016/j.marchem.2006.10.012

Kuypers, M. M. M., Sliekers, A. O., Lavik, G., Schmid, M., Jørgensen, B. B., Kuenen, J. G., .... Jetten, M. S. M. (2003). Anaerobic ammonium oxidation by anammox bacteria in the Black Sea. Nature, 422(6932), 608-611. DOI: 10.1038/nature01472

Lau, M. P., Niederdorfer, R., Sepulveda-Jauregui, A. \& Hupfer, M. (2018). Synthesizing redox biogeochemistry at aquatic interfaces. Limnologica, 68, 59-70. DOI: 10.1016/j.limno. 2017.08.001

Lee, J., Robinson, C. \& Couture, R.-M. (2014). Effect of Groundwater-Lake Interactions on Arsenic Enrichment in Freshwater Beach Aquifers. Environmental Science \& Technology, 48(17), 10174-10181. DOI: 10.1021/es5020136

León-Palmero, E., Morales-Baquero, R. \& Reche, I. (2020). Greenhouse gas fluxes from reservoirs determined by watershed lithology, morphometry, and anthropogenic pressure. Environmental Research Letters, 15(4), 044012. DOI: 10.1088/1748-9326/ab7467

Lewandowski, J., Meinikmann, K., Nützmann, G. \& Rosenberry, D. O. (2015). Groundwater - the disregarded component in lake water and nutrient budgets. Part 2: Effects of groundwater on nutrients. Hydrological Processes, 29(13), 2922-2955. DOI: 10.1002/hyp.10384

Li, S.-J., Hua, Z.-S., Huang, L.-N., Li, J., Shi, S.H., Chen, L.-X., .... Shu, W.-S. (2014). Microbial communities evolve faster in extreme environments. Scientific Reports, 4(1), 6205. DOI: $10.1038 / \mathrm{srep} 06205$

Lister, G. S., Kelts, K., Zao, C. K., Yu, J.-Q. \& Niessen, F. (1991). Lake Qinghai, China: Closed-basin like levels and the oxygen isotope record for ostracoda since the latest Pleistocene. Palaeogeography, Palaeoclimatology, Palaeoecology, 84(1-4), 141-162. DOI: 10.1016/0031-0182(91)90041-O

Litchfield, C. D. (1998). Survival strategies for microorganisms in hypersaline environments and their relevance to life on early Mars. Me- teoritics \& Planetary Science, 33(4), 813-819. DOI: $10.1111 / j .1945-5100.1998 . t b 01688 . x$ Margalef-Marti, R., Carrey, R., Viladés, M., Jubany, I., Vilanova, E., Grau, R., .... Otero, N. (2019). Use of nitrogen and oxygen isotopes of dissolved nitrate to trace field-scale induced denitrification efficiency throughout an in-situ groundwater remediation strategy. Science of The Total Environment, 686, 709-718. DOI: 10.1016/j.scitotenv.2019.06.003

Mariotti, A., Germon, J. C., Hubert, P., Kaiser, P., Letolle, R., Tardieux, A. \& Tardieux, P. (1981). Experimental determination of nitrogen kinetic isotope fractionation: Some principles; illustration for the denitrification and nitrification processes. Plant and Soil, 62(3), 413-430. DOI: 10.1007/BF02374138

Menchén, A., Espín, Y., Valiente, N., Toledo, B., Álvarez-Ortí, M. \& Gómez-Alday, J. J. (2020). Distribution of Endocrine Disruptor Chemicals and Bacteria in Saline Pétrola Lake (Albacete, SE Spain) Protected Area is Strongly Linked to Land Use. Applied Sciences, 10(11), 4017. DOI: 10.3390/app10114017

Mermillod-Blondin, F. (2011). The functional significance of bioturbation and biodeposition on biogeochemical processes at the watersediment interface in freshwater and marine ecosystems. Journal of the North American Benthological Society, 30(3), 770-778. DOI: 10.1899/10-121.1

Messager, M. L., Lehner, B., Grill, G., Nedeva, I. \& Schmitt, O. (2016). Estimating the volume and age of water stored in global lakes using a geo-statistical approach. Nature Communications, 7(1), 13603. DOI: 10.1038/ ncomms 13603

Micklin, P. (2007). The Aral Sea Disaster. Annual Review of Earth and Planetary Sciences, 35(1), 47-72. DOI: 10.1146/annurev. earth.35.031306.140120

Moore, W. S. (1999). The subterranean estuary: A reaction zone of ground water and sea water. Marine Chemistry, 65(1-2), 111-125. DOI: 10.1016/S0304-4203(99)00014-6

Mulder, A., Graaf, A. A., Robertson, L. A. \& Kuenen, J. G. (1995). Anaerobic ammonium oxidation discovered in a denitrifying fluidized bed reactor. FEMS Microbiology Ecol- 
ogy, 16(3), 177-184. DOI: 10.1111/j.15746941.1995.tb00281.x

Nagajyoti, P. C., Lee, K. D. \& Sreekanth, T. V. M. (2010). Heavy metals, occurrence and toxicity for plants: A review. Environmental Chemistry Letters, 8(3), 199-216. DOI: 10.1007/s10311010-0297-8

Nielsen, L. P. (1992). Denitrification in sediment determined from nitrogen isotope pairing. FEMS Microbiology Letters, 86(4), 357-362. DOI: 10.1111/j.1574-6968.1992.tb04828.x

Nriagu, J. O., Wong, H. K. T. \& Coker, R. D. (1982). Deposition and chemistry of pollutant metals in lakes around the smelters at Sudbury, Ontario. Environmental Science \& Technology, 16(9), 551-560. DOI: 10.1021/ es00103a004

Ogato, T., Kifle, D. \& Lemma, B. (2016). Spatio-temporal variations in underwater light climate, thermal and chemical characteristics of the tropical soda lake, Lake Shala, Ethiopia. Limnology, 17(1), 59-69. DOI: 10.1007/ s10201-015-0462-7

Oren, A. (1994). The ecology of the extremely halophilic archaea. FEMS Microbiology Reviews, 13(4), 415-439. DOI: 10.1111/j.15746976.1994.tb00060.x

Oren, A. (2013). Life at High Salt Concentrations. In: E. Rosenberg, E.F. DeLong, S. Lory, E. Stackebrandt, \& F. Thompson (eds.). The Prokaryotes: Prokaryotic Communities and Ecophysiology. (pp. 421-440). Springer Berlin Heidelberg. DOI: 10.1007/978-3-64230123-0 57

Osburn, C. L., Wigdahl, C. R., Fritz, S. C. \& Saros, J. E. (2011). Dissolved organic matter composition and photoreactivity in prairie lakes of the U.S. Great Plains. Limnology and Oceanography, 56(6), 2371-2390. DOI: 10.4319/1o.2011.56.6.2371

Otachi, E. O., Plessl, C., Körner, W., Avenant-Oldewage, A. \& Jirsa, F. (2015). Trace Elements in Water, Sediments and the Elongate Tigerfish Hydrocynus forskahlii (Cuvier 1819) from Lake Turkana, Kenya Including a Comprehensive Health Risk Analysis. Bulletin of Environmental Contamination and Toxicology, 95(3), 286-291. DOI: 10.1007/s00128015-1603-8
Otero, N., Vitòria, L., Soler, A. \& Canals, A. (2005). Fertiliser characterisation: Major, trace and rare earth elements. Applied Geochemistry, 20(8), 1473-1488. DOI: 10.1016/j. apgeochem.2005.04.002

Paredes, I., Otero, N., Soler, A., Green, A. J. \& Soto, D. X. (2020). Agricultural and urban delivered nitrate pollution input to Mediterranean temporary freshwaters. Agriculture, Ecosystems \& Environment, 294, 106859. DOI: 10.1016/j.agee.2020.106859

Paul, V. G. \& Mormile, M. R. (2017). A case for the protection of saline and hypersaline environments: A microbiological perspective. FEMS Microbiology Ecology, 93(8). DOI: 10.1093/femsec/fix091

Pearson, E. J., Juggins, S. \& Farrimond, P. (2008). Distribution and significance of longchain alkenones as salinity and temperature indicators in Spanish saline lake sediments. Geochimica et Cosmochimica Acta, 72(16), 4035-4046. DOI: 10.1016/j.gca.2008.05.052

Pervov, A. G., Andrianov, A. P., Efremov, R. V., Desyatov, A. V. \& Baranov, A. E. (2003). A new solution for the Caspian Sea desalination: Low-pressure membranes. Desalination, 157(1-3), 377-384.DOI: 10.1016/S0011-9164 (03)00420-X

Peura, S., Sinclair, L., Bertilsson, S. \& Eiler, A. (2015). Metagenomic insights into strategies of aerobic and anaerobic carbon and nitrogen transformation in boreal lakes. Scientific Reports, 5(1), 12102. DOI: 10.1038/srep12102

Piña-Ochoa, E. \& Álvarez-Cobelas, M. (2006). Denitrification in Aquatic Environments: A Cross-system Analysis. Biogeochemistry, 81(1), 111-130. DOI: 10.1007/s10533-0069033-7

Plessl, C., Otachi, E. O., Körner, W., Avenant-Oldewage, A. \& Jirsa, F. (2017). Fish as bioindicators for trace element pollution from two contrasting lakes in the Eastern Rift Valley, Kenya: Spatial and temporal aspects. Environmental Science and Pollution Research, 24(24), 19767-19776. DOI: 10.1007/s11356017-9518-z

Porcino, N., Cosenza, A. \& Azzaro, M. (2020). A review on the geochemistry of lakes in Victoria Land(Antarctica). Chemosphere, 251, 126229. 
DOI: 10.1016/j.chemosphere.2020.126229

Post, F. J. (1977). The microbial ecology of the Great Salt Lake. Microbial Ecology, 3(2), 143-165. DOI: 10.1007/BF02010403

Prange, M., Wilke, T. \& Wesselingh, F. P. (2020). The other side of sea level change. Communications Earth \& Environment, 1(1), 69. DOI: 10.1038/s43247-020-00075-6

Prieto-Ballesteros, O., Rodríguez, N., Kargel, J. S., Kessler, C. G., Amils, R. \& Remolar, D. F. (2003). Tírez Lake as a Terrestrial Analog of Europa. Astrobiology, 3(4), 863-877. DOI: 10.1089/153110703322736141

Puig, R., Folch, A., Menció, A., Soler, A. \& MasPla, J. (2013). Multi-isotopic study (15N, 34S, $18 \mathrm{O}, 13 \mathrm{C})$ to identify processes affecting nitrate and sulfate in response to local and regional groundwater mixing in a large-scale flow system. Applied Geochemistry, 32, 129141. DOI: $10.1016 /$ j.apgeochem.2012.10.014

Reati, G. J., Florín, M., Fernández, G. J. \& Montes, C. (1996). The Laguna de Mar Chiquita (Córdoba, Argentina): A little known, secularly fluctuating, saline lake. International Journal of Salt Lake Research, 5(3), 187-219. DOI: 10.1007/BF01997137

Revsbech, N. P. \& Jørgensen, B. B. (1986). Microelectrodes: Their Use in Microbial Ecology. In: K.C. Marshall (ed.). Advances in Microbial Ecology. (Vol. 9, pp. 293-352). Springer US. DOI: 10.1007/978-1-4757-0611-6 7

Risgaard-Petersen, N., Nielsen, L. P., Rysgaard, S., Dalsgaard, T. \& Meyer, R. L. (2003). Application of the isotope pairing technique in sediments where anammox and denitrification coexist. Limnology and Oceanography: Methods, 1(1), 63-73. DOI: 10.4319/1om.2003.1.63

Rivett, M. O., Buss, S. R., Morgan, P., Smith, J. W. N. \& Bemment, C. D. (2008). Nitrate attenuation in groundwater: A review of biogeochemical controlling processes. Water Research, 42(16), 4215-4232. DOI: 10.1016/j.watres. 2008.07.020

Rodríguez-Rodríguez, M. (2007). Hydrogeology of ponds, pools, and playa-lakes of southern Spain. Wetlands, 27(4), 819. DOI: 10.1672/0277-5212(2007)27[819:HOPPAP] 2.0.CO;2

Sakr, S. A. (1999). Validity of a sharp-interface model in a confined coastal aquifer. Hydrogeology Journal, 7(2), 155-160. DOI: 10.1007/ s100400050187

Salk, K. R., Erler, D. V., Eyre, B. D., Carlson-Perret, N., \& Ostrom, N. E. (2017). Unexpectedly high degree of anammox and DNRA in seagrass sediments: Description and application of a revised isotope pairing technique. Geochimica et Cosmochimica Acta, 211, 64-78. DOI: 10.1016/j.gca.2017.05.012

Santoro, A. E. (2010). Microbial nitrogen cycling at the saltwater-freshwater interface. Hydrogeology Journal, 18(1), 187-202. DOI: 10.1007/s10040-009-0526-z

Schagerl, M. (2016). Soda Lakes of East Africa. Springer International Publishing. DOI: 10.1007/978-3-319-28622-8

Schindler, D. E. \& Scheuerell, M. D. (2002). Habitat coupling in lake ecosystems. Oikos, 98(2), 177 189. DOI: 10.1034/j.1600-0706.2002.980201.x Seckbach, J. \& Rampelotto, P. H. (2015). 8 Polyextremophiles. In: C. Bakermans (ed.). Microbial Evolution under Extreme Conditions. (pp. 153-170). De Gruyter. DOI: 10.1515/9783110340716-010

Skidmore, M., Tranter, M., Tulaczyk, S. \& Lanoil, B. (2010). Hydrochemistry of ice stream beds-Evaporitic or microbial effects? Hydrological Processes, 24, 517-523. DOI: 10.1002/ hyp. 7580

Slomp, C. P. \& Van Cappellen, P. (2004). Nutrient inputs to the coastal ocean through submarine groundwater discharge: Controls and potential impact. Journal of Hydrology, 295(1-4), 6486. DOI: $10.1016 /$ j.jhydrol.2004.02.018

Song, G. D., Liu, S. M., Kuypers, M. M. M. \& Lavik, G. (2016). Application of the isotope pairing technique in sediments where anammox, denitrification, and dissimilatory nitrate reduction to ammonium coexist: DNRA and isotope pairing. Limnology and Oceanography: Methods, 14(12), 801-815. DOI: 10.1002/lom3.10127

Sorokin, D. (2011). The Microbial Sulfur Cycle at Extremely Haloalkaline Conditions of Soda Lakes. Frontiers in Microbiology, 2, 44. DOI: 10.3389/fmicb.2011.00044

Sorokin, D. Y., Berben, T., Melton, E. D., Overmars, L., Vavourakis, C. D. \& Muyzer, G. 
(2014). Microbial diversity and biogeochemical cycling in soda lakes. Extremophiles, 18(5), 791-809. DOI: 10.1007/s00792-014-0670-9

Stenger-Kovács, C., Körmendi, K., Lengyel, E., Abonyi, A., Hajnal, É., Szabó, B., .... Padisák, J. (2018). Expanding the trait-based concept of benthic diatoms: Development of trait- and species-based indices for conductivity as the master variable of ecological status in continental saline lakes. Ecological Indicators, 95, 63-74. DOI: 10.1016/j.ecolind.2018.07.026

Stenger-Kovács, C., Lengye, E., Buczkó, K., Tóth, F. M., Crossetti, L. O., Pellinger, A., .... Padisák, J. (2014). Vanishing world: Alkaline, saline lakes in Central Europe and their diatom assemblages. Inland Waters, 4(4), 383-396. DOI: 10.5268/IW-4.4.722

Stojanovic, A., Kogelnig, D., Mitteregger, B., Mader, D., Jirsa, F., Krachler, R. \& Krachler, R. (2009). Major and trace element geochemistry of superficial sediments and suspended particulate matter of shallow saline lakes in Eastern Austria. Geochemistry, 69(3), 223234. DOI: 10.1016/j.chemer.2009.03.001

Stumm, W. \& Morgan, J. J. (1985). Chemical processes in lakes. Workshop, New York. Wiley.

Şuteu, A. M., Momeu, L., Battes, K. P., Baricz, A., Cristea, A., Bulzu, P. A., .... Cîmpean, M. (2021). Diversity and distribution of phototrophic primary producers in saline lakes from Transylvania, Romania. Plant Systematics and Evolution, 307(1), 12. DOI: 10.1007/s00606020-01733-0

Tang, W., Shan, B., Zhang, H., Zhang, W., Zhao, Y., Ding, Y., .... Zhu, X. (2015). Heavy Metal Contamination in the Surface Sediments of Representative Limnetic Ecosystems in Eastern China. Scientific Reports, 4(1), 7152. DOI: 10.1038/srep07152

Tchounwou, P. B., Yedjou, C. G., Patlolla, A. K. \& Sutton, D. J. (2012). Heavy Metal Toxicity and the Environment. In: A. Luch (ed.). Molecular, Clinical and Environmental Toxicolog. (Vol. 101, pp. 133-164). Springer Basel. DOI: 10.1007/978-3-7643-8340-4_6

Thamdrup, B. (2012). New Pathways and Processes in the Global Nitrogen Cycle. Annual Review of Ecology, Evolution, and Systematics, 43(1), 407-428. DOI: 10.1146/annurev- ecolsys-102710-145048

Thamdrup, B., Finster, K., Fossing, H., Hansen, J. W. \& Jørgensen, B. B. (1994). Thiosulfate and sulfite distributions in porewater of marine sediments related to manganese, iron, and sulfur geochemistry. Geochimica et Cosmochimica Acta, 58(1), 67-73. DOI: 10.1016/00167037(94)90446-4

Tiedje, J. M. (1983). Denitrification. In: A.L. Page (ed.). Agronomy Monographs. (pp. 10111026). American Society of Agronomy, Soil Science Society of America. DOI: 10.2134/ agronmonogr9.2.2ed.c47

Trimmer, M., Risgaard-Petersen, N., Nicholls, J. \& Engström, P. (2006). Direct measurement of anaerobic ammonium oxidation (anammox) and denitrification in intact sediment cores. Marine Ecology Progress Series, 326, 37-47. DOI: $10.3354 / \mathrm{meps} 326037$

Valero-Garcés, B. L. \& Kelts, K. R. (1995). A sedimentary facies model for perennial and meromictic saline lakes: Holocene Medicine Lake Basin, South Dakota, USA. Journal of Paleolimnology, 14(2), 123-149. DOI: 10.1007/ BF00735478

Valiente, N., Carrey, R., Otero, N., Soler, A., Sanz, D., Muñoz-Martín, A., .... Gómez-Alday, J. J. (2018). A multi-isotopic approach to investigate the influence of land use on nitrate removal in a highly saline lake-aquifer system. Science of The Total Environment, 631-632, 649-659. DOI: 10.1016/j.scitotenv. 2018.03.059

Valiente, N., Gil-Márquez, J. M., Gómez-Alday, J. J. \& Andreo, B. (2020). Unraveling groundwater functioning and nitrate attenuation in evaporitic karst systems from southern Spain: An isotopic approach. Applied Geochemistry, 123, 104820. DOI: 10.1016/j.apgeochem. 2020.104820

Valiente, N., Gómez-Alday, J. J. \& Jirsa, F. (2019). Spectrophotometric determination of nitrate in hypersaline waters after optimization based on the Box-Behnken design. Microchemical Journal, 145, 951-958. DOI: 10.1016/j.microc. 2018.12.007

van de Graaf, A. A., de Bruijn, P., Robertson, L. A., Jetten, M. S. M. \& Kuenen, J. G. (1997). Metabolic pathway of anaerobic ammonium 
oxidation on the basis of $15 \mathrm{~N}$ studies in a fluidized bed reactor. Microbiology, 143(7), 24152421. DOI: 10.1099/00221287-143-7-2415

van de Graaf, A. A., Mulder, A., de Bruijn, P., Jetten, M. S., Robertson, L. A. \& Kuenen, J. G. (1995). Anaerobic oxidation of ammonium is a biologically mediated process. $A p$ plied and Environmental Microbiology, 61(4), 1246-1251. DOI: 10.1128/AEM.61.4.12461251.1995

Verpoorter, C., Kutser, T., Seekell, D. A. \& Tranvik, L. J. (2014). A global inventory of lakes based on high-resolution satellite imagery. Geophysical Research Letters, 41(18), 63966402. DOI: 10.1002/2014GL060641

Vila, X., Guyoneaud, R., Cristina, X. P., Figueras, J. B. \& Abella, C. A. (2002). Green sulfur bacteria from hypersaline Chiprana Lake (Monegros, Spain): Habitat description and phylogenetic relationship of isolated strains. Photosynthesis Research, 71(1/2), 165-172. DOI: $10.1023 / \mathrm{A}: 1014915900644$

Vincent, W. F. (2018). Lakes: A very short introduction. Oxford University Press.

Vitòria, L., Otero, N., Soler, A. \& Àngels Canals. (2004). Fertilizer Characterization: Isotopic Data (N, S, O, C, and Sr). Environmental Science \& Technology, 38(12), 3254-3262. DOI: 10.1021/es0348187

Vitousek, P. M., Aber, J. D., Howarth, R. W., Likens, G. E., Matson, P. A., Schindler, D. W., .... Tilman, D. G. (1997). Human alteration of the global nitrogen cycle: Sources and consequences. Ecological Applications, 7(3), 737-750. DOI: 10.1890/1051-0761(1997)007[0737: HAOTGN]2.0.CO;2

Voss, M., Bange, H. W., Dippner, J. W., Middelburg, J. J., Montoya, J. P. \& Ward, B. (2013). The marine nitrogen cycle: Recent discoveries, uncertainties and the potential relevance of climate change. Philosophical Transactions of the Royal Society B: Biological Sciences, 368(1621), 20130121. DOI: 10.1098/ rstb.2013.0121

Waiser, M. J. \& Robarts, R. D. (2000). Changes in composition and reactivity of allochthonous DOM in a prairie saline lake. Limnology and Oceanography, 45(4), 763-774. DOI: 10.4319/10.2000.45.4.0763
Walker, K. (1973). Studies on a saline lake ecosystem. Marine and Freshwater Research, 24(1), 21-72.

Wasmund, K., Mußmann, M. \& Loy, A. (2017). The life sulfuric: Microbial ecology of sulfur cycling in marine sediments: Microbial sulfur cycling in marine sediments. Environmental Microbiology Reports, 9(4), 323-344. DOI: 10.1111/1758-2229.12538

Weiner, E. R. (2013). Applications of environmental aquatic chemistry: A practical guide. CRC Press/Taylor \& Francis Group.

Welti, N., Bondar-Kunze, E., Mair, M., Bonin, P., Wanek, W., Pinay, G. \& Hein, T. (2012). Mimicking floodplain reconnection and disconnection using $15 \mathrm{~N}$ mesocosm incubations. Biogeosciences, 9(11), 4263-4278. DOI: 10.5194/ bg-9-4263-2012

Williams, W. D. (1981). Problems in the management of inland saline lakes. SIL Proceedings, 1922-2010, 21(1), 688-692. DOI: 10.1080/03680770.1980.11897069

Williams, W. D. (1996). The largest, highest and lowest lakes of the world: Saline lakes. SIL Proceedings, 1922-2010, 26(1), 61-79. DOI: 10.1080/03680770.1995.11900693

Williams, W. D. (1999). Salinisation: A major threat to water resources in the arid and semi-arid regions of the world. Lakes and Reservoirs: Research and Management, 4(3-4), 85-91. DOI: 10.1046/j.1440-1770.1999.00089.x

Williams, W. D. (2002). Environmental threats to salt lakes and the likely status of inland saline ecosystems in 2025. Environmental Conservation, 29(2), 154-167. DOI: 10.1017/ S0376892902000103

Wooding, R. A., Tyler, S. W., White, I. \& Anderson, P. A. (1997). Convection in groundwater below an evaporating Salt Lake: 2 . Evolution of fingers or plumes. Water Resources Research, 33(6), 1219-1228. DOI: 10.1029/96WR03534

Wurtsbaugh, W. A. \& Berry, T. S. (1990). Cascading Effects of Decreased Salinity on the Plankton Chemistry, and Physics of the Great Salt Lake (Utah). Canadian Journal of Fisheries and Aquatic Sciences, 47(1), 100-109. DOI: 10.1139/f90-010

Wurtsbaugh, W. A., Miller, C., Null, S. E., 
DeRose, R. J., Wilcock, P., Hahnenberger, M., Howe, F. \& Moore, J. (2017). Decline of the world's saline lakes. Nature Geoscience, 10(11), 816-821. DOI: 10.1038/ngeo3052

Yang, H., Andersen, T., Dörsch, P., Tominaga, K., Thrane, J.-E. \& Hessen, D. O. (2015). Greenhouse gas metabolism in Nordic boreal lakes. Biogeochemistry, 126(1-2), 211-225. DOI: 10.1007/s10533-015-0154-8

Yechieli, Y., Gavrieli, I., Berkowitz, B. \& Ronen, D. (1998). Will the Dead Sea die?. Geology, 26(8), 755-758. DOI: 10.1130/00917613(1998)026<0755:WTDSD $>2.3 . C O ; 2$

Yechieli, Y. \& Wood, W. W. (2002). Hydrogeologic processes in saline systems: Playas, sabkhas, and saline lakes. Earth-Science Reviews, 58(3-4), 343-365. DOI: $10.1016 /$ S00128252(02)00067-3

Yechieli, Y. (1993). The effects of water level changes in closed lakes (Dead Sea) on the surrounding groundwater and country rocks. $(\mathrm{PhD}$. Thesis. Weizmann Institute of Science, Israel). Retrieved: https://weizmann.primo. exlibrisgroup.com/permalink/972WIS_INST/ 9kbs33/alma990000450650203596

Zadereev, E., Lipka, O., Karimov, B., Krylenko, M., Elias, V., Pinto, I. S., .... Fischer, M. (2020). Overview of past, current, and future ecosystem and biodiversity trends of inland saline lakes of Europe and Central Asia. Inland Waters, 10(4), 438-452. DOI: 10.1080/20442041.2020.1772034

Zamkovaya, T., Foster, J. S., de Crécy-Lagard, V. \& Conesa, A. (2021). A network approach to elucidate and prioritize microbial dark matter in microbial communities. The ISME Journal, 15(1), 228-244. DOI: 10.1038/s41396-02000777-x

Zimmermann, S., Bauer, P., Held, R., Kinzelbach, W. \& Walther, J. H. (2006). Salt transport on islands in the Okavango Delta: Numerical investigations. Advances in Water Resources, 29(1), 11-29. DOI: 10.1016/j.advwatres. 2005.04.013

Zumft, W. G. (1997). Cell biology and molecular basis of denitrification. Microbiology and Molecular Biology Reviews: MMBR, 61(4), 533616. DOI: $10.1128 / \mathrm{mmbr} .61 .4 .533-616.1997$ 